LLL BANCO CENTRAL DO BRASIL

\title{
The Finance-Growth Nexus: the role of banks
}

Thiago Christiano Silva, Benjamin Miranda Tabak and Marcela Tetzner Laiz

September 2019

Working Papers
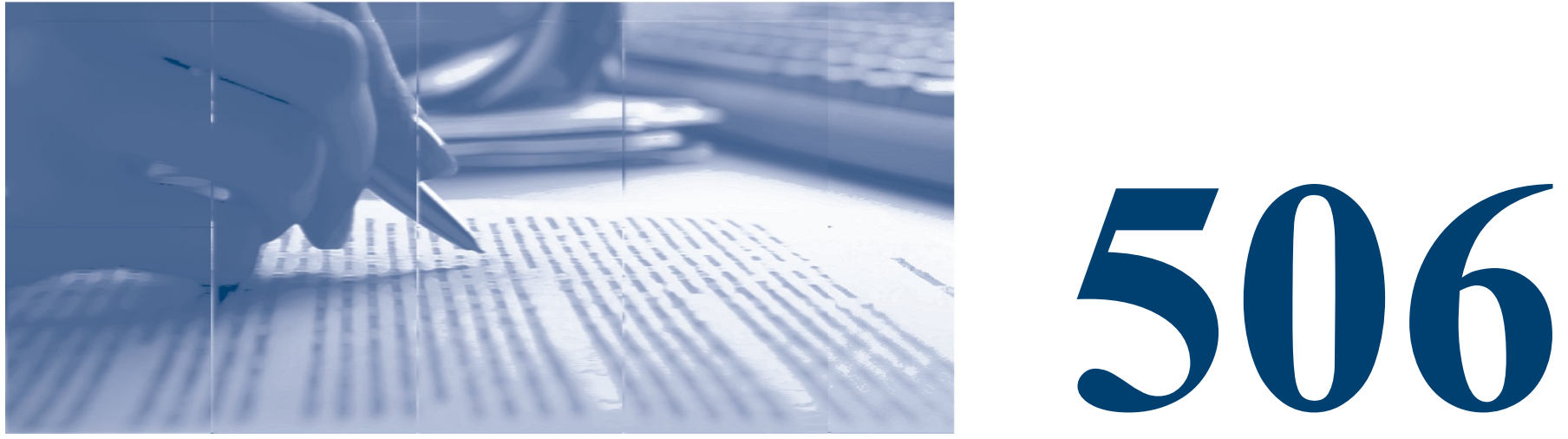
ISSN 1518-3548

CGC 00.038.166/0001-05

p. $1-36$ 


\section{Working Paper Series}

Edited by the Research Department (Depep) - E-mail: workingpaper@bcb.gov.br

Editor: Francisco Marcos Rodrigues Figueiredo

Co-editor: José Valentim Machado Vicente

Head of the Research Department: André Minella

Deputy Governor for Economic Policy: Carlos Viana de Carvalho

The Banco Central do Brasil Working Papers are evaluated in double blind referee process.

Although the Working Papers often represent preliminary work, citation of source is required when used or reproduced.

The views expressed in this Working Paper are those of the authors and do not necessarily reflect those of the Banco Central do Brasil.

As opiniões expressas neste trabalho são exclusivamente do(s) autor(es) e não refletem, necessariamente, a visão do Banco Central do Brasil.

\section{Citizen Service Division}

Banco Central do Brasil

Deati/Diate

SBS - Quadra 3 - Bloco B - Edifício-Sede $-2^{\circ}$ subsolo

70074-900 Brasília - DF - Brazil

Toll Free: 08009792345

Fax: +55 (61) 3414-2553

Internet: http//www.bcb.gov.br/?CONTACTUS 


\section{Non-Technical Summary}

Most studies in the finance-growth nexus literature use data from several countries to conduct their empirical analyses, which may be hard to interpret due to the diversity in historical experiences, cultural norms and institutional contexts. We use a rich database of Brazilian municipalities and their respective stage of financial development to test the role of financial development in economic growth. The dataset has more than 5,500 municipalities with high heterogeneity, allowing a more comprehensive analysis of the relationship between financial and economic development.

The financial development of a region can be seen as a mechanism to accelerate its economic growth. While we find a statistically significant link of the finance-growth nexus in Brazil, such relationship underwent changes after the global financial crisis. Our results suggest that non-earmarked credit has a strong association with higher economic growth rates than earmarked credit. However, the association between earmarked credit and economic growth became stronger after 2008 .

We further investigate the role of different credit modalities in economic growth. We find that general-purpose, purpose-specific, and other types of loans have a positive association with economic growth. However, we find that purpose-specific loans are relatively more important to explain economic growth. However, after the global financial crisis, general-purpose loans correlate stronger with economic growth. Other credit operations tend to matter less.

We also find that credit from state-owned, domestic private and foreign banks associates with municipal economic growth. Our results suggest that credit from domestic private banks strongly associates with higher economic growth rates of Brazilian municipalities. In addition, after the global financial crisis, the correlation between credit from state-owned banks and growth becomes more pronounced relative to the pre-crisis period. In what concerns bank type, credit from commercial banks associates more strongly with higher economic growth rates. 


\section{Sumário Não Técnico}

A maioria dos estudos na literatura do "finance-growth nexus" utiliza dados de vários países para realizar análises empíricas, o que pode gerar dificuldades na interpretação em função da diversidade de experiências históricas, normas culturais e contextos institucionais. Utilizamos uma rica base de dados de municípios brasileiros e de seus respectivos estágios de desenvolvimento financeiro para testar o papel do desenvolvimento financeiro no crescimento econômico em cidades brasileiras. A base de dados possui mais de 5.500 municípios com alta heterogeneidade, permitindo uma análise mais abrangente da relação entre desenvolvimento financeiro e econômico.

O desenvolvimento financeiro de uma região pode ser visto como um mecanismo propulsor de seu crescimento econômico. Apesar de encontrarmos uma ligação estatisticamente significante do "finance-growth nexus" no Brasil, tal relacionamento sofreu mudanças após a crise financeira global. Nossos resultados sugerem uma forte associação entre crédito não direcionado e maiores taxas de crescimento econômico dos municípios relativamente a crédito direcionado. No entanto, a associação entre crédito direcionado e crescimento econômico se fortaleceu após 2008 .

Investigamos ainda o papel das diferentes modalidades de crédito no crescimento econômico. Verificamos que a correlação de empréstimos, financiamento e de outros tipos de empréstimos com crescimento econômico é positiva. Em especial, verificamos que crédito para financiamento é relativamente mais importante para explicar o crescimento econômico. No entanto, depois da crise global de 2008, empréstimos para fins gerais se correlacionam mais fortemente com crescimento econômico. Outras operações de crédito tendem a importar menos.

Verificamos que crédito de bancos públicos, privados e estrangeiros se associa a crescimento econômico. Os resultados sugerem que crédito de bancos privados se associa significativamente com o crescimento econômico dos municípios brasileiros. Além disso, após a crise de 2008, a correlação entre crédito de bancos públicos e crescimento fica mais forte relativamente ao período pré-crise. No que diz respeito ao tipo de banco, crédito de bancos comerciais se associa mais fortemente com altas taxas de crescimento econômico. 


\title{
The Finance-Growth Nexus: the role of banks
}

\author{
Thiago Christiano Silva* \\ Benjamin Miranda Tabak ${ }^{* *}$ \\ Marcela Tetzner Laiz ${ }^{* * *}$
}

\begin{abstract}
We contribute to the finance-growth nexus literature by showing that credit origin, bank ownership, credit modality and bank type matter for economic growth. We use a unique dataset covering 5,555 municipalities in the Brazilian economy with granular information on credit characteristics. We find that non-earmarked credit to the corporate sector associates with municipal economic growth more strongly than earmarked credit, despite the increase in relevance of the latter after the global financial crisis. We also find that the credit modality-whether it is general purpose or purpose-specific loans-associates with economic growth in different ways. Overall, credit provided by domestic private banks to the corporate sector correlates with higher economic growth rates. In contrast, only after the crisis the relationship between credit from state-owned banks and economic growth becomes statistically significant. While we follow the finance-growth literature in our empirical exercises using internal instruments in GMM estimations, we also provide robustness tests using two additional external instruments: the number of complaints filed against each bank and the local credit accessibility. Our results with external instruments indicate the same findings with respect to the use of traditional internal instruments in GMM estimations.
\end{abstract}

Keywords: financial development, economic growth, finance-growth nexus, banking system. JEL Classification: O47; G32; G21; F15; F18; C10.

The Working Papers should not be reported as representing the views of the Banco Central do Brasil. The views expressed in the papers are those of the authors and do not necessarily reflect those of the Banco Central do Brasil.

\footnotetext{
*Research Department, Banco Central do Brasil, e-mail: thiago.silva@bcb.gov.br

**FGV/EPPG, Escola de Políticas Públicas e Governo, Fundação Getúlio Vargas (School of Public Policy and Government, Getulio Vargas Foundation), Brasília, DF. E-mail: benjaminm.tabak@gmail.com

*** Universidade Católica de Brasília, e-mail: marcela.tetzner@gmail.com
} 


\section{Introduction}

Over the past years, significant effort has been put on the debate of the finance-growth nexus and the role of banks. We contribute to the literature by studying the finance-growth nexus in Brazil using unique datasets. First, we explore how different credit characteristics relate to economic growth. Second, we analyze whether the link between financial development and economic growth has changed after the global financial crisis. By matching unique data on granular loan-level credit operations to the corporate sector and municipality-level economic and social development indicators, we analyze the association of credit from state-owned, domestic-private and foreign banks to local economic growth. We also outline the association of economic growth and credit from commercial, investment, development banks, and credit unions within each Brazilian municipality. We also look whether different credit modalities-i.e. those with a specific purpose or not-correlate with economic growth of municipalities. While we find a statistically significant link of the finance-growth nexus in Brazil, we find that such relationship underwent changes after the global financial crisis (GFC).

Many studies regarding the finance-growth nexus use cross-country data, which is hard to interpret due to the diversity in historical experiences, cultural norms and institutional contexts. That is why we focus on domestic municipality-level data of Brazilian municipalities. Brazil is a relevant emerging market country and experienced a tremendous credit growth in the mid-2000s, especially between 2004 and 2008. According to the Brazilian Institute of Geography and Statistics (IBGE), GDP reached a significant positive annual growth rate of 6\% in 2007 and 2008, just before the GFC. Comparing 2008 with 2003, gross domestic product increased 26.5\%, which is equivalent to an average annual growth of $4.8 \%$.

While the fast credit growth seems to have fueled economic growth to some extent, the pace of economic growth has been somewhat lower. The question of how the quality of lending and who gets the credit affects economic growth is very relevant for policy makers. This fact becomes even more important for the Brazilian case because of its bank-oriented economy. As capital markets are underdeveloped, bank credit turns out to be the only source of external funding for the average firm. In this way, the role of bank financing in economic growth stands out as an important point worth investigating.

Brazil's financial and banking systems are the largest in Latin America. The Brazilian banking system comprises financial institutions with diverse ownership structures. State-owned banks have an important presence and hold a significant share of the corporate and housing markets. There is a strong intervention of the federal government in the form of prudential regulation, price regulation, and direct quantity regulation through subsidized loans. Credit in the Brazilian banking system is usually grouped into earmarked and non-earmarked credit.

Earmarked loans comprise a relevant share of the Brazilian credit market and are directed to specific sectors or activities through resources regulated by law. These include mandatory lending to specific sectors, such as to small rural producers or to a subset of households that are financing specific assets, such as low-income families buying their first houses. The supply of long-term credit 
is mainly in the form of earmarked loans. These loans are granted within government programs that seek to address specific market failures in the banking system. For example, most of the lending to housing is earmarked, and interest rates are lower than market rates that are in place for other types of non-earmarked loans. In this paper, we show that the relationship between bank financing and economic growth differs for earmarked and non-earmarked credit.

It is not clear the relative relevance of state-owned and privately-held banks to economic growth. While they may differ in several aspects, such as institutional arrangements and goals, it is an empirical question to test whether such distinctions may complement each other and generate more pronounced economic growth rates. For instance, Brazilian state-owned banks behaved countercyclically during the global financial crises as a conduit for policy making. Has this change in stance had an impact in municipal economic growth? Additionally, due to the higher information asymmetries, does the role of foreign banks in economic growth change during distressed times, such as the GFC? Our empirical exercises contribute to these questions by documenting how financial development associates with economic growth from several bank- and loan-specific characteristics, adding important contributions to the literature.

There are empirical identification challenges in the finance-growth literature as financial development endogenously relates to economic growth. Endogeneity can lead to inconsistent estimates and incorrect inferences, which may provide misleading conclusions and inappropriate theoretical interpretations. To mitigate endogeneity, the finance-growth literature usually resorts to GMM estimations with internal instruments in contrast to the usual OLS estimation. Internal instruments normally include first-differenced or in-levels lagged values of endogenous (instrumented) regressors. However, if there is any structure between the endogenous variable with their past values-which is very likely in most cases - then endogeneity is still a concern (Blundell and Bond (1998)).

This paper does not tackle the issue of causality between financial development and economic growth. Instead, we document a series of statistical relationships between bank financing and local economic growth in different perspectives. We follow the standard finance-growth literature and use a dynamic panel-data estimation (Blundell and Bond (1998)) with internal instruments. To complement these results, we also run two-stage instrumental regressions, in which we instrument financial development using two external instruments. In the first, we instrument bank-specific credit growth with the number of complaints municipality-specific residents file against that bank. As residents' complaints increase, credit demand for that bank tends to decrease and the bank credit growth is likely to reduce. In the second, we instrument credit growth with a proxy for credit accessibility within the city. The more accessible banks are, the more likely residents will engage in credit operations with those banks. Our results remain qualitatively unchanged over different specifications regardless of the use of internal or external instruments or the estimation method.

Our results show that the non-earmarked credit associates with economic growth more strongly than with earmarked credit. However, we find evidence that earmarked credit becomes more relevant for economic growth than non-earmarked credit after the onset of the GFC, which may be partly explained by the observed counter-cyclical behavior in the credit market of state-owned banks after 
the crisis.

We also find that credit modality matters for economic growth 1 We find that purpose-specific loans are relatively more important to explain economic growth than general purpose loans or other credit operations. However, after the GFC, our estimates change, and general purpose loans correlate more strongly with growth. These findings may be partly explained by the fact that financially constrained (small) firms may have demanded more short-term credit to withstand the unexpected negative events arising from the sudden increase in risk aversion and decrease in international demand for goods and suppliers.

We also find that state-owned, domestic private and foreign banks associate positively with economic growth. Our results suggest that domestic private banks play an essential role in the economic growth of Brazilian municipalities. However, after the GFC, the presence of state-owned banks correlates stronger with higher economic growth relative to the pre-crisis period. In what concerns bank type, commercial banks are more relevant to explain growth. After the GFC, foreign banks reduced their activities in the Brazilian banking system, decreasing their lending and their importance for local economic growth relative to domestic private and state-owned banks. We also find that credit unions correlate with growth especially after the GFC, despite holding a relatively small market share and being more concentrated in specific regions in Brazil.

We also study others determinants that relate to economic growth besides financial development, such as income distribution, social inequality, and development levels from the education, income, and health perspectives. Worse income distribution tends to reduce economic growth. Demirguc-Kunt and Levine (2008) focus on re-distributive policies to reduce inequality with positive effects on economic growth. As reviewed by Aghion et al. (1999), some models suggest that public policies that redistribute income from the rich to the poor reduce the negative growth effects of income inequality and therefore boost aggregate growth. In turn, Beck et al. (2007) propose an alternative policy approach in which financial sectors reforms should be aimed at reducing market frictions and to lower income inequality and boost growth, without the potential incentive problems associated with re-distributive policies. Our work documents statistical evidence of the role of other variables that may influence economic growth apart from financial development variables.

The remainder of the paper is structured as follow. Section 2 describes a brief literature review. Section 3 documents the data. Section 4 discusses the econometric methodology. Section 5 introduces the empirical results. Section 6 draws policy implications. Section 7 concludes the paper.

\footnotetext{
${ }^{1}$ We divide credit modality as follows. General purpose loans include short-term loans to cover up liquidity needs, while purpose-specific loans encompass, among others, loans to finance specific assets, such as houses and cars. Other credit operations include leasing.
} 


\section{Literature Review}

There is not yet a consensus in the literature about the debate of the finance-growth nexus and the role of banks. A strand of the literature suggests a positive relationship between financial development and economic growth or, more specifically, that financial intermediaries exert a positive impact on growth (King and Levine (1993), Beck et al. (2000), Koop et al. (2000), Levine (2005), Beck et al.(2014b)). We present a summary of the recent literature findings' on the impact of financial development on economic growth in Table 1 .

Jayaratne and Strahan (1996) find that rates of real per capita growth in income and output increase significantly following intrastate branch reform, showing that improvements in the quality of bank lending - and not increased volume of lending - appear to be responsible for faster growth rates. In the same vein, Beck et al. (2015) document the importance of finance for entrepreneurship and microenterprise growth, both of which being conduits for municipal economic growth.

Beck and Levine (2004) and Abedifar et al.(2016) show that stock markets and banks positively influence economic growth, implying a positive relationship between the market share of banks and the development of financial intermediation, financial deepening and economic welfare. More credit provided by efficient banks exerts a complementary growth effect in addition to the direct quantity and quality channel effects (Hasan et al. (2009)).

Even though banks may differ significantly in terms of individual financial profiles-such as capital buffer levels, asset quality, earnings, liquidity, management quality —and even institutional goals, Doumpos et al. (2017) show that the difference of the overall financial profiles between Islamic and conventional banks is not statistically significant. Despite competing in the same banking system, there is empirical evidence showing that Islamic banks showed stronger resilience during the GFC (Hasan and Dridi (2011). Breitenlechner et al. (2015) demonstrate that while financial development is positively linked to GDP growth in normal times, larger financial sectors lead to significantly worse economic outcomes in the case of a banking crisis, highlighting that the finance-growth nexus depends on the current macroeconomic conditions of the economy.

Some authors find that the impact of finance on growth is positive and significant only up to a certain point. Soedarmono et al. (2017) find that higher financial development measured by financial deepening and financial intermediation exhibits an inverted U-shaped relationship with economic growth, suggesting a non-linear effect. Beck et al. (2014a) defend that an expansion of credit has a positive effect on per capita output growth only up to a certain point, due to financial cycles and nonintermediation activities in banks' business model. After a certain threshold, further development of finance tends to adversely affect growth (Law and Singh (2014)). More precisely, Law et al. (2013) suggest that the financial development growth nexus is contingent on the level of institutional quality, supporting the idea that better finance is potent in delivering long-run economic development.

In contrast to these researches, the other strand in the finance-growth literature shows controversial results or reverse causation in this relationship. Demetriades and Hussein (1996) demonstrate 
little support to the view that finance is a leading sector in the process of economic development. Notwithstanding, after the GFC, the idea that the relationship between financial development and economic growth is not quite so straightforward started to gain support. Loayza and Ranciere (2006) find that indicators of credit can be used as predictors of crises, and therefore, in the short run, financial development may be associated with financial volatility and crises, exerting a negative influence on economic growth.

Indeed, in order to deepen this discussion, there is a literature that studies the impact of financial development on economic growth volatility, measured by the standard deviation of GDP per capita growth. Easterly et al. (2001), for example, find evidence of a U-shaped effect of private credit on growth volatility. Beck et al. (2006), on the other hand, find that higher private credit may reduce and increase the impacts of real and monetary volatility, respectively, especially if stock markets are underdeveloped, suggesting a negative relation between financial development and volatility. Furthermore, Beck et al. (2014b) find that financial intermediation increases growth and reduces volatility in the long run, but these effects become weaker when considering a shorter and more recent time horizon. Mallick (2009) decomposes growth volatility into business-cycle and long-run components, and finds that the development of financial intermediaries reduces business-cycle volatility, but has no effect in the long run. Finally, Silva et al. (2017) find a non-linear relation of financial development on growth volatility: as finance gets deeper, growth volatility will increase faster than the average growth itself. Results suggests that increasing the level of domestic credit may intensify the relative volatility in the medium term, but still raises relative long-term growth before the long-run threshold is achieved.

\section{Data Description}

We match municipality-level data from the IBGE with loan-level data from the Brazilian Credit Risk Bureau (SCR) ${ }^{2}$ which is a unique and proprietary data set from the BCB that contains loan-level data on bank credit to firms. We aggregate the outstanding credit that banks grant to firms located in each of these municipalities to compose the total credit that municipalities receive from the banking sector. Due to the richness in the loan-level credit dataset, we are able to take different forms of credit aggregation within the city, such as credit by bank control, bank type and credit modality to test for different aspects of the finance-growth nexus.

Our sample is an unbalanced panel data of 5,555 Brazilian municipalities that goes from 2003

\footnotetext{
${ }^{2}$ The SCR is a database that provides the BCB with the information it needs to supervise and monitor the credit market, as well as evaluate the credit portfolio of financial institutions. It has operations and securities along with credit characteristics and respective guarantees contracted by individuals and legal entities before financial institutions in the country. The SCR is fed monthly by financial institutions. The SCR is not a restrictive register because there is both positive and negative information. Until March 2012, the operations of customers with total liability equal to or greater than $\mathrm{R} \$ 5,000$, due and expired, and amounts related to guarantees provided by financial institutions to their clients were maintained in the database of the SCR. From April 2012, this amount has been reduced to R\$ 1 thousand. For credit unions and credit companies to the small entrepreneurs and for the small business, the value changes only from July of 2012.
} 
Table 1: Summary of the findings on the impact of financial development on economic growth

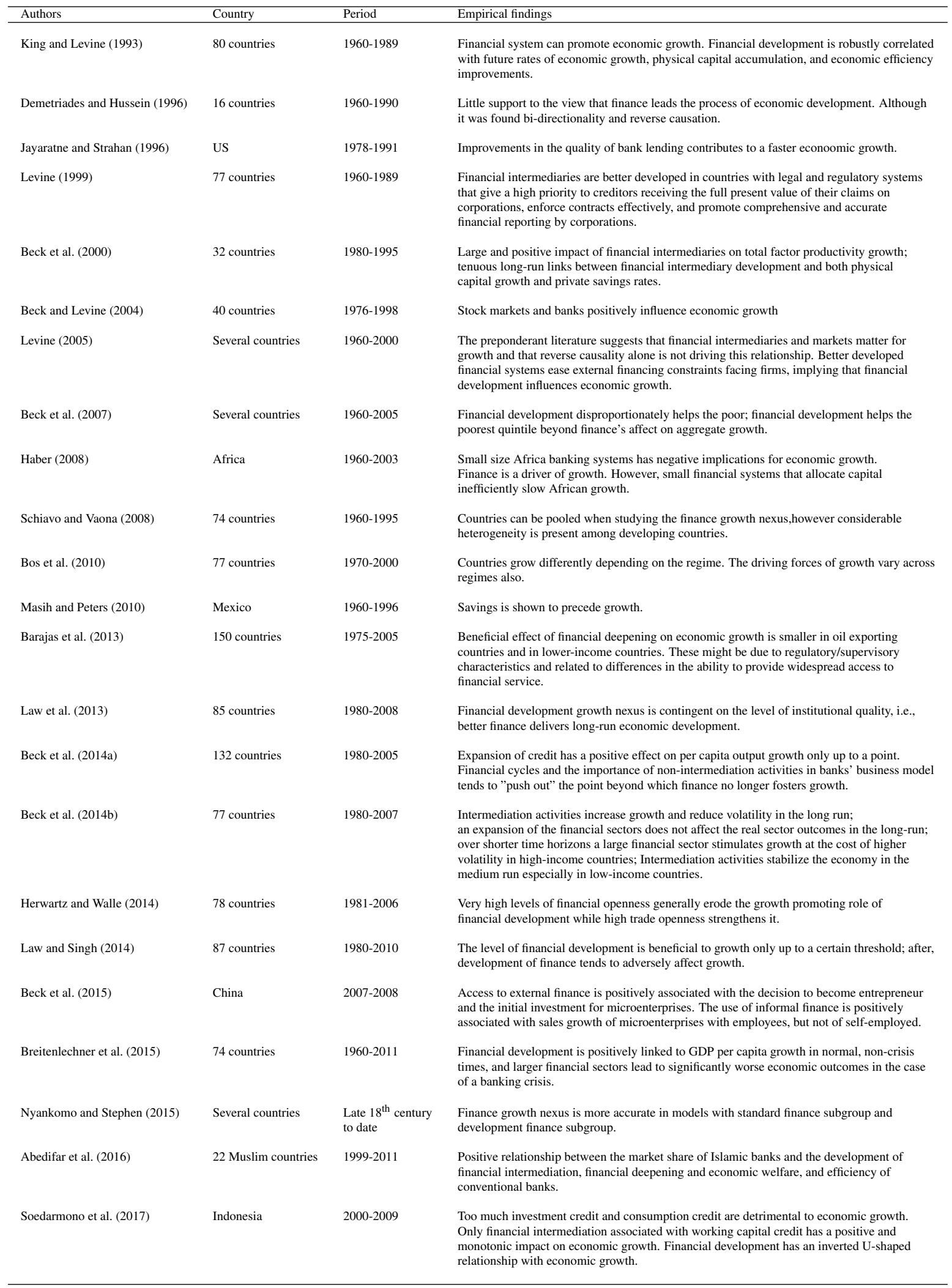


to 2014 , with a total of 66,271 observations of annual data. This panel data is an innovation over previous studies, since we are able to better study differences in the impact of the finance-growth nexus using bank- and loan-specific characteristic across Brazilian cities.

Table 2 shows the number of active outstanding credit operations in Brazil as registered by the SCR from 2003 to 2014. We segregate the total number of operations by regions. The vast majority of credit operations takes place in the Southeast, followed by the South region, which are the two most developed regions in Brazil. The North region has the lowest number of credit operations. The increase of outstanding credit operations in Brazil along 2003 to 2014 is partly due to legal changes that reduced the threshold above which operations become mandatory to be reported to the SCR.

Table 2: Number of active credit operations in Brazil reported in the SCR from 2003 to 2014.

\begin{tabular}{ccccccc}
\hline Year & \multicolumn{5}{c}{ Number of credit operations (in millions) } \\
& Midwest & North & Northeast & South & Southeast & Total \\
\hline $\mathbf{2 0 0 3}$ & 23.68 & 9.05 & 5.14 & 3.46 & 1.56 & $\mathbf{4 2 . 8 9}$ \\
$\mathbf{2 0 0 5}$ & 33.26 & 13.35 & 7.14 & 5.26 & 2.44 & $\mathbf{6 1 . 4 4}$ \\
$\mathbf{2 0 0 6}$ & 37.66 & 14.82 & 8.13 & 5.77 & 2.76 & $\mathbf{6 9 . 1 3}$ \\
$\mathbf{2 0 0 7}$ & 40.79 & 16.00 & 9.51 & 6.41 & 3.16 & $\mathbf{7 5 . 8 8}$ \\
$\mathbf{2 0 0 8}$ & 51.48 & 20.94 & 12.58 & 8.28 & 4.21 & $\mathbf{9 7 . 4 8}$ \\
$\mathbf{2 0 0 9}$ & 61.22 & 25.97 & 15.37 & 10.15 & 5.08 & $\mathbf{1 1 7 . 8 0}$ \\
$\mathbf{2 0 1 0}$ & 68.27 & 29.83 & 17.98 & 11.66 & 5.74 & $\mathbf{1 3 3 . 4 8}$ \\
$\mathbf{2 0 1 1}$ & 75.93 & 33.56 & 21.35 & 13.31 & 6.64 & $\mathbf{1 5 0 . 8 0}$ \\
$\mathbf{2 0 1 2}$ & 250.31 & 101.60 & 74.00 & 39.95 & 17.46 & $\mathbf{4 8 3 . 3 1}$ \\
$\mathbf{2 0 1 3}$ & 272.63 & 111.11 & 78.30 & 42.27 & 18.63 & $\mathbf{5 2 2 . 9 4}$ \\
$\mathbf{2 0 1 4}$ & 264.92 & 107.98 & 78.07 & 42.78 & 18.39 & $\mathbf{5 1 2 . 1 4}$ \\
\hline Total & $\mathbf{1 , 1 8 0 . 1 5}$ & $\mathbf{4 8 4 . 2 1}$ & $\mathbf{3 2 7 . 5 5}$ & $\mathbf{1 8 9 . 2 9}$ & $\mathbf{8 6 . 0 7}$ & $\mathbf{2 , 2 6 7 . 2 8}$ \\
\hline
\end{tabular}

Figure 1 shows the evolution of the ratio of earmarked and non-earmarked credit to the regional GDP over time. Earmarked credit rapidly increased after the GFC partly due to a anti-cyclical policy conducted by the government via state-owned banks. The Midwest, Northeast and North had the largest earmarked credit / GDP growth rates after the GFC. In contrast, non-earmarked credit growth / GDP rate significantly decreased after the GFC, especially in the South and Southeast regions.

Figure 2 portrays the evolution of different types of credit by region and over time. We split credit in general purpose credit and purpose-specific credit. While there is a decrease in growth rates of general purpose credit / GDP after the GFC, the local importance of purpose-specific credit significantly increased after the GFC. Given the pronounced disparities among Brazilian regions, it is important to observe how regions differ. Bank credit is mostly channeled to the Southeast and South regions, which are the most developed in Brazil.

Figure 3 depicts the evolution of credit broken down by bank control: state-owned, domestic private and foreign. We can see increasing growth rates in outstanding credit / GDP by state-owned banks, especially in the less developed regions. In parallel, credit granted by domestic private and foreign banks stabilized in some regions after the GFC, while in others it decreased.

Figure 4 displays the evolution of credit broken down by bank type: commercial banks, invest- 


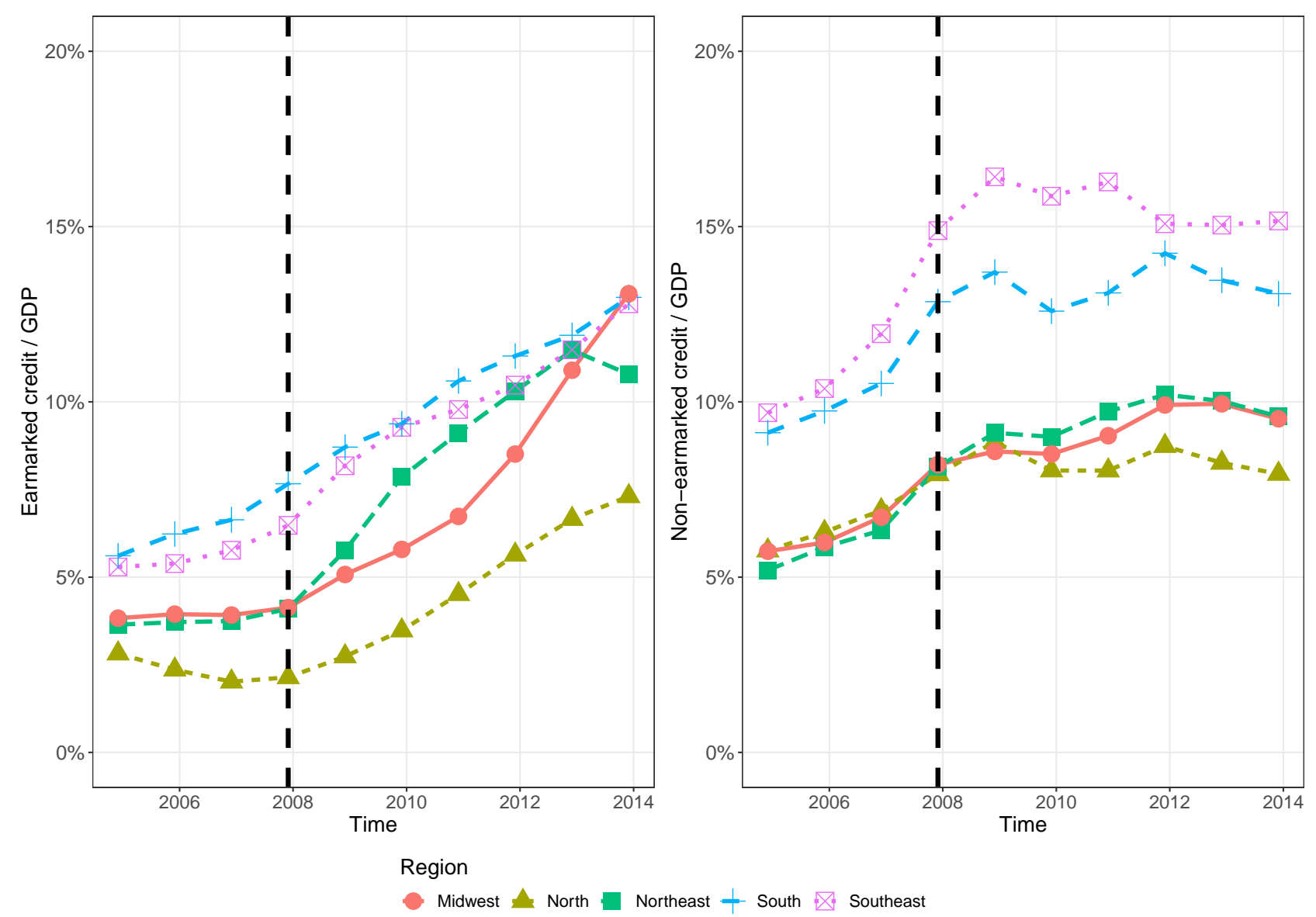

Figure 1: Evolution of earmarked and non-earmarked credit in terms of regional GDP in Brazil from 2003 to 2014.

ment banks, credit unions and development banks. The most relevant bank type are commercial banks with a share of regional GDP of almost $20 \%$ for some regions, and higher than $10 \%$ in all regions. Development banks also play an important role in credit concession and their relevance depends on the specific region. In the North region, development banks hold a share lower than $2 \%$, whereas in the Southeast, they have approximately $6 \%$ of the regional GDP. The local importance of credit unions in granting credit rapidly increased after 2009, especially in the South and Midwest regions, which are locations in which credit unions have a stronger presence.

For municipality-level controls, we use the Gini index and the Human Development Index (HDI) that come from the IBGE. The Gini index is a measure of the degree of inequality of a distribution whose value ranges from zero (perfect equality) to one (the maximum inequality). The HDI measures human development in three dimensions-income, education and health- ${ }^{3}$ and is defined

\footnotetext{
${ }^{3}$ The three components are evaluated as follows. Income: Life standard is measured by the municipal income per capita, that is, the average income of the residents of a given municipality. It is the sum of the income of all residents, divided by the number of people living in the municipality - including children and people without income records. Education: Access to knowledge is measured by two indicators. Adult schooling is measured by the percentage of people with 18 years old or more who have completed elementary schooling. Young population flux is measured by the arithmetic mean of the percentage of children aged 5 to 6 attending school, the percentage of young people between the ages of 11 and 13 attending the final years of elementary education, the percentage of young people between 15 and 17 years old with complete primary education, and the percentage of young people between the ages of 18 and 20 with full secondary education. The measure accompanies the school-age population in four key moments of their education. This makes it easier for managers to identify whether children and young people are in the right grade at the right ages. The geometric mean of these two components results in the IDHM Education. Health: Long and healthy life is measured by the life
} 

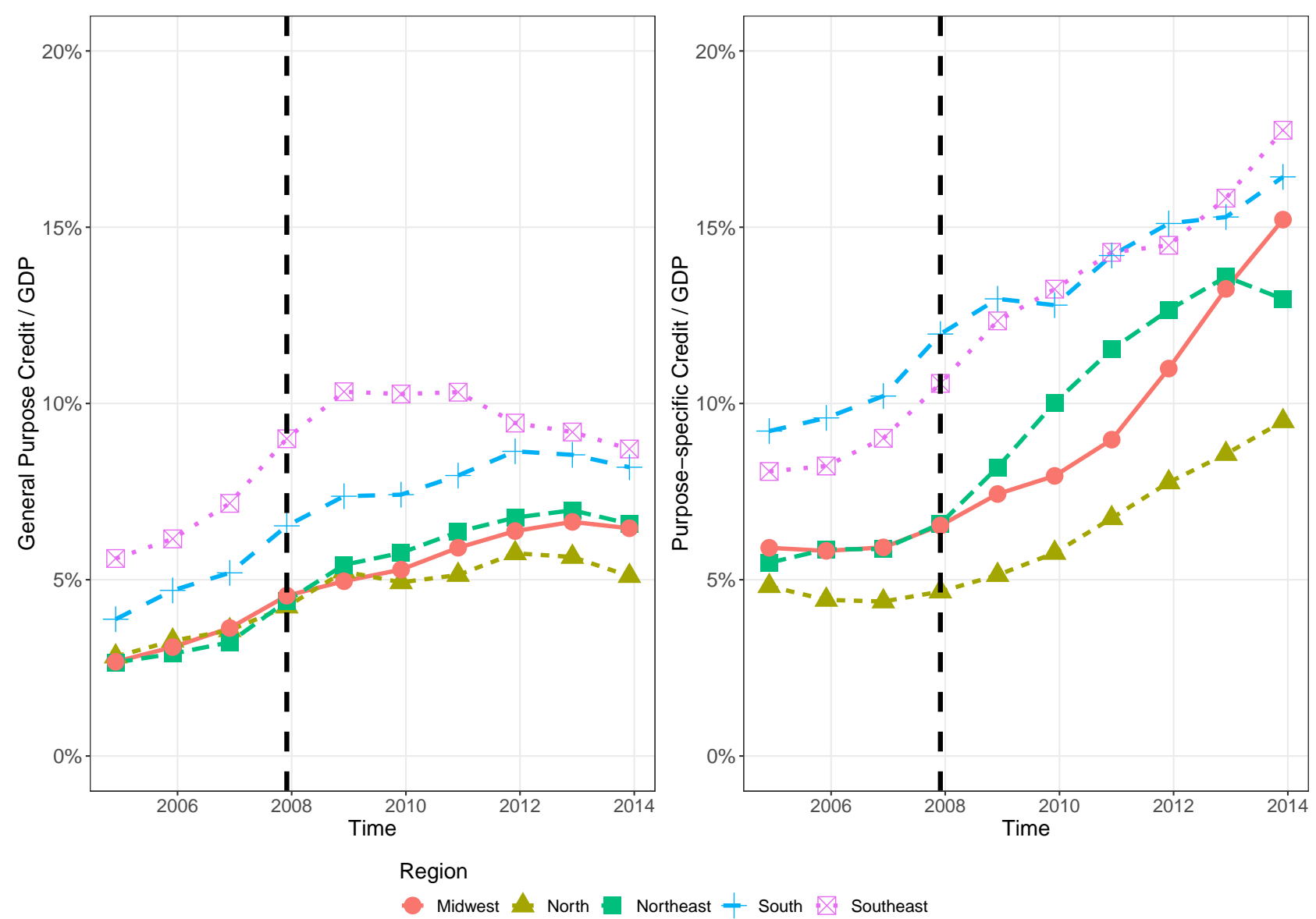

Figure 2: Evolution of the general purpose credit and purpose-specific credit in terms of regional GDP in Brazil from 2003 to 2014 

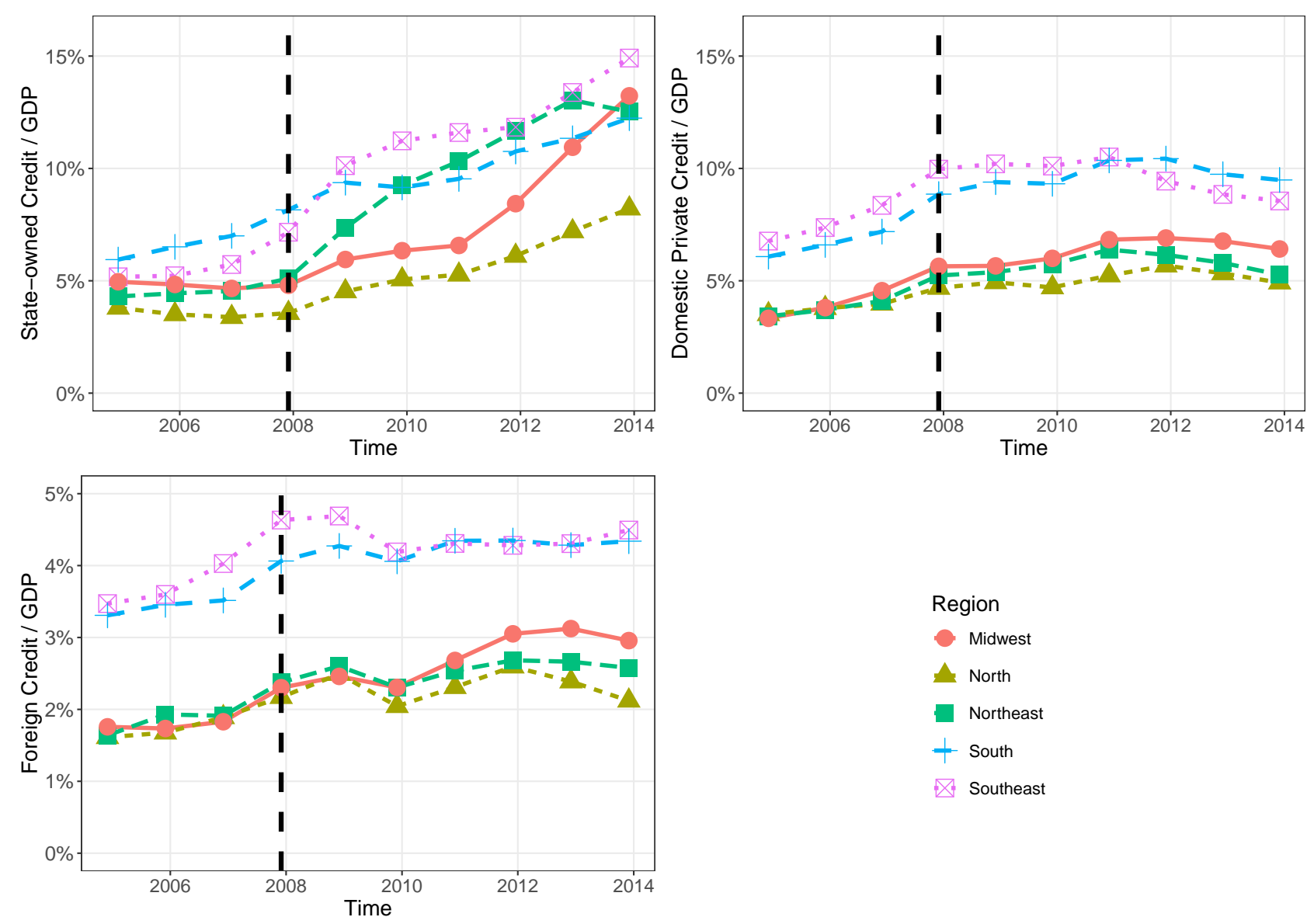

Region

- Midwest

A North

Northeast

$\perp$ South

Southeast

Figure 3: Evolution of credit broken down by bank control (state-owned, domestic private and foreign) in terms of regional GDP in Brazil from 2003 to 2014. 

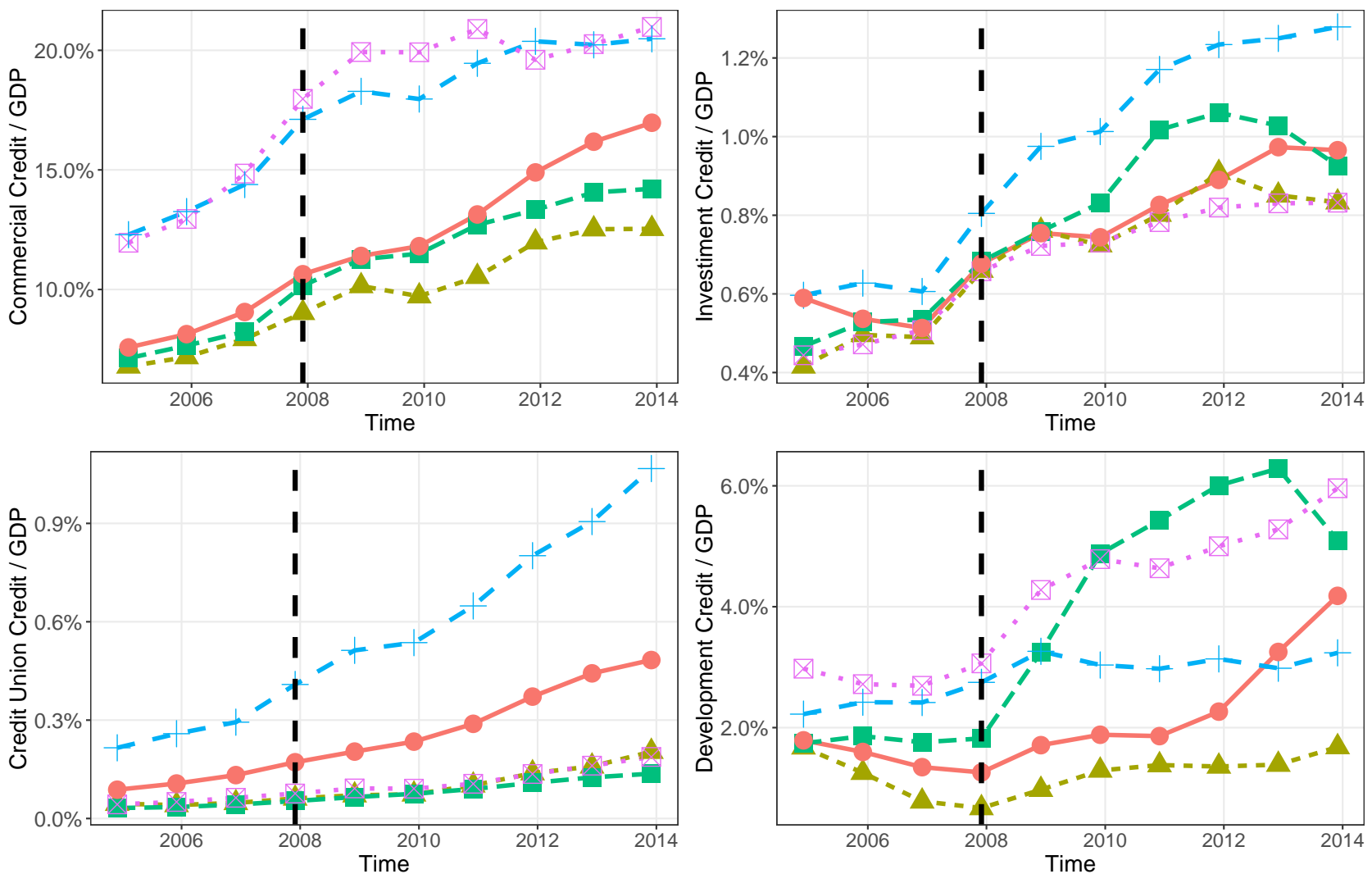

Region

Midwest North Northeast $\perp$ South $\otimes$ Southeast

Figure 4: Evolution of credit broken down by bank type (commercial, investment, credit union, development) in terms of regional GDP in Brazil from 2003 to 2014. 
as the geometric mean of each of the dimensions.

Table 3 shows the summary statistics of the variables employed in our empirical specification. Dependent variables and financial development variables are evaluated in growth rates. Growth rates of financial development variables are taken with respect to the municipal GDP levels. On average, non-earmarked credit growth rates are higher than that of earmarked credit, particularly after the GFC. Non-purpose specific and purpose-specific credit have similar growth rates on average. Domestic private and foreign banks have higher credit / GDP growth rates than state-owned banks, especially before the GFC. Credit unions have the largest credit / GDP growth rates, mostly after 2009. Municipality-level social and development variables are evaluated in levels. The amplitude and standard deviations of the financial development variables are high, which demonstrates the heterogeneity of the credit pattern over Brazilian cities.

Table 3: Summary statistics of the variables employed in our empirical specification.

\begin{tabular}{|c|c|c|c|c|c|c|c|}
\hline Statistic & $\mathrm{N}$ & Mean & St. Dev. & Min & $\operatorname{Pctl}(25)$ & $\operatorname{Pctl}(75)$ & Max \\
\hline \multicolumn{8}{|l|}{ Dependent variables } \\
\hline Per capita growth & 60,653 & 0.101 & 0.142 & -1.756 & 0.043 & 0.160 & 4.108 \\
\hline Per capita growth volatility & 60,653 & 0.022 & 0.034 & 0.000 & 0.034 & 0.312 & 0.862 \\
\hline \multicolumn{8}{|c|}{ Financial development / municipal GDP variables (in growth rates) } \\
\hline Non-earmarked credit & 60,655 & 0.539 & 1.234 & -11.479 & 0.076 & 0.551 & 14.761 \\
\hline Earmarked credit & 60,655 & 0.661 & 1.886 & -13.858 & 0.024 & 0.616 & 16.806 \\
\hline Non-purpose specific credit & 60,655 & 0.579 & 1.275 & -10.411 & 0.098 & 0.579 & 14.735 \\
\hline Purpose-specific credit & 60,655 & 0.600 & 1.731 & -13.858 & 0.029 & 0.569 & 16.861 \\
\hline Other credit & 60,655 & 0.595 & 2.201 & -13.648 & -0.106 & 0.710 & 14.965 \\
\hline State-owned bank credit & 60,655 & 0.496 & 1.088 & -12.060 & 0.076 & 0.488 & 13.278 \\
\hline Domestic private bank credit & 60,655 & 0.603 & 1.615 & -14.958 & 0.010 & 0.598 & 15.553 \\
\hline Foreign bank credit & 60,655 & 0.609 & 2.544 & -15.187 & -0.038 & 0.602 & 18.247 \\
\hline Commercial bank credit & 60,655 & 0.474 & 0.876 & -9.332 & 0.083 & 0.458 & 10.625 \\
\hline Investment bank credit & 60,655 & 0.698 & 2.885 & -15.187 & -0.011 & 0.612 & 15.581 \\
\hline Credit union credit & 60,655 & 0.794 & 2.845 & -12.859 & 0.000 & 0.446 & 17.392 \\
\hline Development bank credit & 60,655 & 0.259 & 2.243 & -18.344 & 0.000 & 0.000 & 20.598 \\
\hline \multicolumn{8}{|c|}{ Municipality-level variables (in levels) } \\
\hline Gini & 66,271 & 0.514 & 0.066 & 0.099 & 0.472 & 0.557 & 0.808 \\
\hline Municipal HDI (Income) & 66,271 & 0.628 & 0.084 & 0.371 & 0.558 & 0.695 & 0.891 \\
\hline Municipal HDI (Education) & 66,271 & 0.512 & 0.112 & 0.108 & 0.435 & 0.596 & 0.825 \\
\hline Municipal HDI (Health) & 66,271 & 0.784 & 0.052 & 0.580 & 0.749 & 0.824 & 0.894 \\
\hline
\end{tabular}

\section{Model Specification}

The empirical specification is designed to test the nexus between financial development and the role of banks in city's economic growth and its volatility. We test whether financial development increases growth and whether this relationship differs depending on bank and credit operation charac-

expectancy at birth, calculated by an indirect method, based on data from the IBGE Demographic Census. This indicator shows the average number of years that a person born in a given municipality would live from birth, maintaining the same mortality standards. 
teristics. We also test if the finance-growth nexus changes after the GFC. We estimate the following baseline model 4

$$
Y_{i t}=\alpha+\rho Y_{i, t-1}+\beta \text { Finance }_{i t}+\gamma \text { Controls }_{i t}+\kappa \text { Crisis }_{t}+\eta \text { Crisis }_{t} \times \text { Finance }_{i t}+\varepsilon_{i t},
$$

in which $Y_{i t}$ takes the traditional form employed in the literature to measure the increase of welfare and its volatility: the per capita nominal GDP growth rate (growth) and its standard deviation (volatility). Finance $_{i t}$ measures different impacts of financial development variables on growth and is used in the regressions always as growth rates. Controls ${ }_{i t}$ stands for municipality-level controls. Crisis $s_{t}$ is the dummy for the GFC that started in 2008. We interact the financial development variables with the GFC dummy to test whether the role of banks changes after the crisis. $\varepsilon_{i t}$ is the error term. $Y_{i, t-1}$ is the autoregressive term that captures inertial characteristics of the GDP growth and its volatility. All economic and financial development variables are employed in the natural logarithm form and hence coefficients are elasticities.

There are empirical challenges in the finance-growth literature as financial development endogenously relates to economic growth. Our empirical specifications do not tackle the issue of causality between financial development and economic growth. Instead, we document a series of statistical relationships between bank financing and local economic growth in different perspectives. To alleviate endogeneity, the finance-growth literature usually resorts to GMM estimations with internal instruments in contrast to the usual OLS estimation. We follow such procedure and use Blundell and Bond (1998)'s System GMM estimator, which includes first-differenced and in-levels variables to instrument the endogenous regressors (internal instruments). 5 We assume that all financial development and municipality-level characteristics are endogenous.

To check the validity of our estimations using dynamic panel-data, we use two statistical tests that are standard in the literature. In the first, if the second-order serial correlation is statistically insignificant, $A R(2)$, then the System-GMM estimator is consistent. In the second, we employ the Sargan test to verify whether the instruments are valid (over-identifying restrictions). The Sargan test has an asymptotic distribution of $\chi^{2}$ under the null that the instruments are valid. To complement these results, we also run two-stage instrumental regressions, in which we instrument financial development using two external instruments. In the first, we instrument bank-specific credit growth with the number of complaints municipality-specific residents file against that bank. As residents' complaints increase, credit demand for that bank tends to decrease and the bank credit growth is likely to reduce. In the second, we instrument credit growth with a proxy for credit accessibility within the city. The more accessible banks are, the more likely residents will engage in credit operations with

\footnotetext{
${ }^{4}$ Our baseline model is a dynamic panel-data model because the autoregressive coefficient $\rho$ is statistically significant in all specifications.

${ }^{5}$ The OLS method does not control for endogeneity issues, such as reverse causality. It is possible that our measures of financial development are affected by the present and past levels of GDP growth and its volatility. The approach we take in the paper is an attempt to minimize this problem. An important requirement of the System-GMM estimator is that the number of time series observations be small relative to the size of cross-section, which is satisfied by our specification.
} 
those banks.

To test the impact of credit origin on economic growth and its volatility in Brazilian municipalities, we include earmarked and non-earmarked loans as financial development variables. Earmarked loans are directed to certain sectors or activities, carried out with resources regulated by law or regulation. This includes mandatory lending to specific sectors, granted within government programs that seek to address specific market failures in the banking system.

We also verify the different impacts of credit modality on growth and its volatility. In this respect, we test whether general purpose, purpose-specific loans and other credit operations influence economic growth and its volatility in different manners. We also analyze the role of the bank type (commercial, investment, credit union, and development) in economic growth and its volatility.

We test the different reactions of state-owned, domestic private, and foreign banks. We expect to find different effects, since bank types differ in several ways. Staub et al. (2010) show that foreign banks have improved their performance in what concerns the establishment of new affiliates and the acquisition of local banks. However, despite having improved cost efficiency, state-owned banks are profit inefficient.

\section{Empirical Results}

This section presents empirical results for the nexus between financial development and growth, and the role of banks in Brazil. The broad picture of our results supports our hypotheses, even though coefficient estimates and confidence levels vary from equation to equation and across tables.

Table 4 reports our coefficient estimates of the impact of credit origin, i.e. earmarked and nonearmarked, on growth and volatility. Non-earmarked and earmarked credit have a positive association with economic growth. However, the association of non-earmarked credit is relatively stronger. Specifically, an increase of $1 \%$ in non-earmarked credit associates with an increase of $4.1 \%$ in municipal economic growth, while an increase of $1 \%$ in earmarked credit links with an increase of $0.7 \%$. The result is maintained when control variables are included in the model, as observed in Column (3): an increase of $1 \%$ in non-earmarked credit relates to an increase of $3.7 \%$ in growth, while an increase of $1 \%$ in earmarked credit correlates with a $1.1 \%$ increase in economic growth. ${ }^{6}$ However, those implications are not observed over growth volatility.

The National Economic and Social Development Bank (BNDES), the biggest Brazilian Development Bank, plays a major role in earmarking credit for industrial and infrastructure projects. However, even though those loans are quite relevant, our results show that non-earmarked credit play a more incisive role in terms of economic growth.

Costa and Mello (2008) show that earmarked credit scheme has several implications for pricing and competition, since it increases the marginal funding cost of banks and thus renders the non-

\footnotetext{
${ }^{6}$ We find strong evidence that these coefficients are statistically different.
} 
Table 4: Regression results that test the role of earmarked and non-earmarked credit in economic growth. We run the dynamic panel-data specification: $Y_{i t}=\alpha+\rho Y_{i, t-1}+\beta$ Finance $_{i t}+\gamma$ Controls $_{i t}+\kappa C r i s i s_{t}+\eta$ Crisis $_{t} \times$ Finance $_{i t}+\varepsilon_{i t}$. $Y_{i t}$ is the per capita GDP growth (Columns 1 and 3) and its volatility (Columns 2 and 4) for Brazilian municipalities. Finance $_{i t}$ is our financial development variables: local growth rates of earmarked and non-earmarked credit in terms of local GDP. We interact them with Crisis $s_{t}$, a GFC dummy that starts in 2008. Controls $s_{\text {it }}$ are city-level controls (Gini and HDI). We assume that financial development and city-level variables are endogenous and estimate the dynamic panel using Blundell and Bond (1998)'s System GMM. We report tests for second-order serial correlation (AR-2) and instrument validity (Sargan).

\begin{tabular}{|c|c|c|c|c|}
\hline Sample Period: 2003-2014 & $\begin{array}{c}(1) \\
\text { Growth }\end{array}$ & $\begin{array}{c}(2) \\
\text { Volatility }\end{array}$ & $\begin{array}{c}\text { (3) } \\
\text { Growth }\end{array}$ & $\begin{array}{c}(4) \\
\text { Volatility }\end{array}$ \\
\hline $\begin{array}{l}\text { Autoregressive coefficient } \\
\text { Per capita growth } \\
i, t-1\end{array}$ & $\begin{array}{c}-0.032^{* * *} \\
(0.0101)\end{array}$ & $\begin{array}{c}0.008^{* * *} \\
(0.002)\end{array}$ & $\begin{array}{c}-0.035^{* * *} \\
(0.0111)\end{array}$ & $\begin{array}{c}0.007^{* * *} \\
(0.002)\end{array}$ \\
\hline \multicolumn{5}{|c|}{ Endogenous financial development variables } \\
\hline Non-earmarked credit $_{i t}$ & $\begin{array}{l}0.041^{* * *} \\
(0.0024)\end{array}$ & $\begin{array}{c}0.022 \\
(0.0168)\end{array}$ & $\begin{array}{l}0.037^{* * *} \\
(0.0029)\end{array}$ & $\begin{array}{c}-0.002 \\
(0.0172)\end{array}$ \\
\hline Earmarked credit $_{i t}$ & $\begin{array}{l}0.007^{* * *} \\
(0.0022)\end{array}$ & $\begin{array}{c}-0.013 \\
(0.0144)\end{array}$ & $\begin{array}{l}0.011^{* * *} \\
(0.0022)\end{array}$ & $\begin{array}{c}-0.001 \\
(0.0145)\end{array}$ \\
\hline Crisis $_{t} \times$ non-earmarked credit ${ }_{i t}$ & $\begin{array}{l}-0.004^{* * *} \\
(0.0011)\end{array}$ & $\begin{array}{c}-0.011 \\
(0.0175)\end{array}$ & $\begin{array}{c}-0.003^{* * *} \\
(0.0009)\end{array}$ & $\begin{array}{c}0.009 \\
(0.0099)\end{array}$ \\
\hline Crisis $_{t} \times$ earmarked credit $_{i t}$ & $\begin{array}{l}0.007^{* * *} \\
(0.0012)\end{array}$ & $\begin{array}{c}0.021^{* *} \\
(0.0199)\end{array}$ & $\begin{array}{l}0.009^{* * *} \\
(0.0019)\end{array}$ & $\begin{array}{c}0.016 \\
(0.0096)\end{array}$ \\
\hline \multicolumn{5}{|l|}{ Endogenous city-level characteristics } \\
\hline Gini index $_{i t}$ & & & $\begin{array}{c}-0.177^{* * *} \\
(0.0371)\end{array}$ & $\begin{array}{c}-0.901^{* * *} \\
(0.1989)\end{array}$ \\
\hline HDI-Income $_{i t}$ & & & $\begin{array}{l}0.317^{* * *} \\
(0.0673)\end{array}$ & $\begin{array}{l}3.477^{* * *} \\
(0.6128)\end{array}$ \\
\hline HDI-Education $_{i t}$ & & & $\begin{array}{l}0.362^{* * *} \\
(0.0511)\end{array}$ & $\begin{array}{l}0.872^{* *} \\
(0.3011)\end{array}$ \\
\hline HDI-Health $_{i t}$ & & & $\begin{array}{l}0.507^{* * *} \\
(0.0722)\end{array}$ & $\begin{array}{l}1.121^{* *} \\
(0.5538)\end{array}$ \\
\hline Number of observations & 55,070 & 55,070 & 55,070 & 55,070 \\
\hline Number of instruments & 52 & 52 & 52 & 52 \\
\hline AR-2 (p-value) & 0.195 & 0.252 & 0.228 & 0.251 \\
\hline Sargan (p-value) & 0.119 & 0.235 & 0.149 & 0.296 \\
\hline
\end{tabular}

Standard errors in parentheses

${ }^{*} p<0.10,{ }^{* *} p<0.05,{ }^{* * *} p<0.01$ 
earmarked credit segment more expensive. Moreover, the authors show that market-based lending cross-subsidize earmarked lending. They measure the impact of earmarked lending on spreads of non-earmarked loans and find that $7.6 \%$ of the spread is due to the mortgage and rural credit. Thus, the dual nature of the financial intermediation has an adverse impact on market-based lending.

By analyzing the behavior of earmarked and non-earmarked credit after the GFC, we find that earmarked credit gained more importance to foster economic growth. This result is maintained when control variables are not included (Column 1) as well as when control variables for cities are included (Column 3). The result is in line with the study of De Mello and Garcia (2012), who show that earmarked credit increased in 2008 as a policy response to the 2008 credit crunch. This might be do to the fact that after the GFC, the government used the BNDES as the main agent for anti-cyclical parafiscal policy. In what concerns the role of non-earmarked credit, our results show that the association of such credit with municipal growth became weaker after the GFC.

The Gini index has a significantly negative link with growth, meaning that a worse income distribution reduces growth. As expected and in line with our results, a large set of works finds this negative relationship between inequality and growth (Clarke (1995), Easterly and Levine (2003), Persson and Tabellini (1994)). Gini Index also has a positive impact over volatility (the standard deviation of growth). We also find that an increase in the HDI-Income, HDI-Education, HDI-Health has a positive association with growth and volatility, suggesting that the city development level, measured by income, education and health, may increase growth and its volatility.

Table 5 describes the relationship between credit modality (general purpose, purpose-specific, and other credit operations), economic growth, and growth volatility. We find that those three credit modalities are relevant for economic growth. The results hold after controlling for municipality-level variables. Purpose-specific credit correlates more strongly with economic growth than the other credit types, suggesting that such credit modality is the one that may impact growth the most. Beck et al. (2015), when studying Chinese rural households, find the importance of purpose-specific loans for entrepreneurship and micro-enterprise growth, as informal finance is positively associated with sales growth of micro-enterprises with employees. Levine (2005) shows that a better developed financial system ease external financing constraints facing firms, suggesting that financial development influences economic growth. We also find that, after the GFC, general purpose loans gained importance to the economic growth of cities (Columns 1 and 3). Results are robust after controlling for municipality-level variables.

In what concerns the impact of financial development on economic growth volatility, our results show that the interaction between the GFC dummy and purpose-specific loans is the only statistically significant coefficient (Columns 2 and 4). The coefficient suggests that more purpose-specific credit is positively correlated with higher growth volatility after the GFC.7

Tabak et al. (2011) test empirically whether banks operating within the Brazilian banking system concentrate or diversify their credit portfolio and how this choice impacts their performance and

7 Easterly et al. (2001), who show that the volatility of an economy will differ across countries according to the nature of the shocks they face, the structure of the economy, and the policy regime of the government. 
Table 5: Regression results that test the role of different credit modalities in economic growth. We run the dynamic panel-data specification: $Y_{i t}=\alpha+\rho Y_{i, t-1}+\beta$ Finance $_{i t}+\gamma$ Controls $_{i t}+\kappa$ Crisis $_{t}+\eta$ Crisis $_{t} \times$ Finance $_{i t}+\varepsilon_{i t} . Y_{i t}$ is the per capita GDP growth (Columns 1 and 3) and its volatility (Columns 2 and 4) for Brazilian municipalities. Finance ${ }_{i t}$ is our financial development variables: local growth rates of general purpose and purpose-specific loans, and other credit operations in terms of local GDP. We interact them with Crisis $s_{t}$, a GFC dummy that starts in 2008. Controls it $_{\text {are }}$ city-level controls (Gini and HDI). We assume that financial development and city-level variables are endogenous and estimate the dynamic panel using Blundell and Bond (1998)'s System GMM. We report tests for second-order serial correlation (AR-2) and instrument validity (Sargan).

\begin{tabular}{|c|c|c|c|c|}
\hline & $\begin{array}{c}\text { (1) } \\
\text { Growth }\end{array}$ & $\begin{array}{c}(2) \\
\text { Volatility }\end{array}$ & $\begin{array}{c}(3) \\
\text { Growth }\end{array}$ & $\begin{array}{c}(4) \\
\text { Volatility }\end{array}$ \\
\hline $\begin{array}{l}\text { Autoregressive coefficient } \\
\text { Per capita growth } \\
i, t-1\end{array}$ & $\begin{array}{c}-0.029^{* * *} \\
(0.0087)\end{array}$ & $\begin{array}{c}0.007^{* * *} \\
(0.002)\end{array}$ & $\begin{array}{c}-0.031^{* * *} \\
(0.0091)\end{array}$ & $\begin{array}{c}0.007^{* * *} \\
(0.002)\end{array}$ \\
\hline $\begin{array}{l}\text { Endogenous financial developr } \\
\text { General-purpose loans }_{i t}\end{array}$ & $\begin{array}{c}0.012^{* * *} \\
(0.0032)\end{array}$ & $\begin{array}{c}0.046 \\
(0.0495)\end{array}$ & $\begin{array}{c}0.008^{* *} \\
(0.0037)\end{array}$ & $\begin{array}{c}0.052 \\
(0.0514)\end{array}$ \\
\hline Purpose-specific loans ${ }_{i t}$ & $\begin{array}{l}0.022^{* * *} \\
(0.0027)\end{array}$ & $\begin{array}{c}-0.014 \\
(0.0179)\end{array}$ & $\begin{array}{l}0.023^{* * *} \\
(0.0027)\end{array}$ & $\begin{array}{c}-0.011 \\
(0.0196)\end{array}$ \\
\hline Other credit ops. ${ }_{i t}$ & $\begin{array}{c}0.012 \\
(0.0213)\end{array}$ & $\begin{array}{c}-0.018 \\
(0.0334)\end{array}$ & $\begin{array}{c}0.014 \\
(0.0196)\end{array}$ & $\begin{array}{c}-0.012 \\
(0.0302)\end{array}$ \\
\hline Crisis $_{t} \times$ General-purpose $_{i t}$ & $\begin{array}{c}0.008^{* *} \\
(0.0035)\end{array}$ & $\begin{array}{c}-0.020 \\
(0.0201)\end{array}$ & $\begin{array}{l}0.009^{* * *} \\
(0.0021)\end{array}$ & $\begin{array}{c}-0.016 \\
(0.0189)\end{array}$ \\
\hline Crisis $_{t} \times$ Purpose-specific $_{i t}$ & $\begin{array}{c}0.000 \\
(0.0018)\end{array}$ & $\begin{array}{c}0.026^{* *} \\
(0.0113)\end{array}$ & $\begin{array}{c}-0.000 \\
(0.0018)\end{array}$ & $\begin{array}{c}0.021^{*} \\
(0.0066)\end{array}$ \\
\hline Crisis $_{t} \times$ Other credit ops $_{i t}$ & $\begin{array}{c}-0.003 \\
(0.0219)\end{array}$ & $\begin{array}{c}0.005 \\
(0.0125)\end{array}$ & $\begin{array}{c}-0.003 \\
(0.0214)\end{array}$ & $\begin{array}{c}0.003 \\
(0.0125)\end{array}$ \\
\hline $\begin{array}{l}\text { Endogenous city-level charact } \\
\text { Gini index }_{i t}\end{array}$ & ristics & & $\begin{array}{l}-0.101^{*} \\
(0.0546)\end{array}$ & $\begin{array}{r}-0.621^{* * *} \\
(0.2104)\end{array}$ \\
\hline HDI-Income $_{i t}$ & & & $\begin{array}{l}0.291^{* * *} \\
(0.0872)\end{array}$ & $\begin{array}{l}3.101^{* * *} \\
(0.6102)\end{array}$ \\
\hline HDI-Education $_{i t}$ & & & $\begin{array}{l}0.304^{* * *} \\
(0.0375)\end{array}$ & $\begin{array}{c}0.102 \\
(0.5286)\end{array}$ \\
\hline HDI-Health $_{i t}$ & & & $\begin{array}{l}0.470^{* * *} \\
(0.1106)\end{array}$ & $\begin{array}{c}0.802 \\
(1.0295)\end{array}$ \\
\hline Number of observations & 55,070 & 55,070 & 55,070 & 55,070 \\
\hline Number of instruments & 52 & 52 & 52 & 52 \\
\hline AR-2 (p-value) & 0.163 & 0.221 & 0.202 & 0.252 \\
\hline Sargan (p-value) & 0.134 & 0.286 & 0.157 & 0.314 \\
\hline
\end{tabular}

Standard errors in parentheses

${ }^{*} p<0.10,{ }^{* *} p<0.05,{ }^{* * *} p<0.01$ 
risk. Results suggest that loan portfolio concentration increases returns and also reduces default risk. The impact of concentration on bank returns is decreasing on bank risk. There are significant size effects, and foreign and state-owned banks seem to be less affected by the degree of diversification. Additionally, they show an increasing concentration trend after the breakout of the GFC.

Moreover, in what concerns our income inequality analysis, we find that Gini Index associates negatively with growth and volatility. The HDI indexes for income, education and health have a positive and statistically significant association with growth, while only the HDI-Income associates positively with volatility.

Table 6 reports regression results of the role of bank control in economic growth. We break down credit / GDP growth rates in terms state-owned, domestic private and foreign banks. Our results show that state-owned, domestic private and foreign banks correlates positively growth, even though their importance changed after the GFC.

Using a statistical test for mean differences in the coefficients, our estimates indicate that the statistical relationship between domestic private bank and economic growth is stronger than that of state-owned and foreign banks before the GFC. However, this difference vanishes when compared to state-owned banks after the GFC, time at which the importance of domestic private banks decreased while that of state-owned increased. This increased importance of state-owned banks after the GFC is in line with Bonomo et al. (2015), who show that the government-driven credit had an important role in countervailing the private credit crunch in Brazil during the GFC. The importance of foreign banks to economic growth after the crisis diminished as well, though it remained positive and statistically significant. After the GFC, domestic private banks correlate positively with growth volatility while foreign banks show an opposite pattern.

Table 7 reports regression results for the role of bank type in economic growth and its volatility. We split credit / GDP growth rates into commercial, investment, development banks and credit unions. Commercial banks have the strongest association with growth and volatility. This might be due to the capacity and facility of commercial banks to create financial capital currency 8 investment banks, however, do not explain growth, although they reduce volatility.

Aghion (1999) shows the relevance of development banking to industrialization and economic development. He focuses on the role of development banks in fostering the acquisition and dissemination of expertise in long-term industrial finance. As shown by Torres and Zeidan (2016), development banks are an important government tool for earmarking credit in Brazil. However, there is no consensus on the effectiveness of national development banks for economic growth. While, on the one hand, government-led credit allocation can help countries faced with financial repression and incomplete and inefficient capital markets, on the other hand, it may hinder the development of efficient capital markets. However, most of the developed countries have at some point used, or still use, development banks.

8 Abedifar et al. (2016) find that the presence of Islamic commercial banks and their conventional counterparts in the same market can foster finance and financial deepening and improve economic welfare. 
Table 6: Regression results that test the role of bank control in economic growth. We run the dynamic panel-data specification: $Y_{i t}=\alpha+\rho Y_{i, t-1}+\beta$ Finance $_{i t}+\gamma$ Controls $_{i t}+\kappa$ Crisis $_{t}+\eta$ Crisis $_{t} \times$ Finance $_{i t}+\varepsilon_{i t} . Y_{i t}$ is the per capita GDP growth (Columns 1 and 3) and its volatility (Columns 2 and 4) for Brazilian municipalities. Finance it is our financial development variables: local credit growth rates granted by state-owned, domestic private and foreign banks in terms of

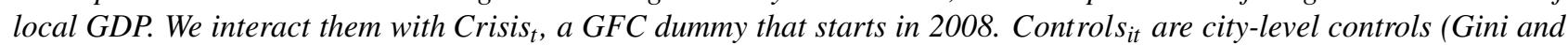
HDI). We assume that financial development and city-level variables are endogenous and estimate the dynamic panel using Blundell and Bond (1998)'s System GMM. We report tests for second-order serial correlation (AR-2) and instrument validity (Sargan).

\begin{tabular}{|c|c|c|c|c|}
\hline & $\begin{array}{c}\text { (1) } \\
\text { Growth }\end{array}$ & $\begin{array}{c}(2) \\
\text { Volatility }\end{array}$ & $\begin{array}{l}\text { (3) } \\
\text { Growth }\end{array}$ & $\begin{array}{c}(4) \\
\text { Volatility }\end{array}$ \\
\hline $\begin{array}{l}\text { Autoregressive coefficient } \\
\text { Per capita growth } \\
i, t-1\end{array}$ & $\begin{array}{c}-0.030^{* * *} \\
(0.0094)\end{array}$ & $\begin{array}{c}0.006^{* * *} \\
(0.002)\end{array}$ & $\begin{array}{l}-0.029^{* * *} \\
(0.0089)\end{array}$ & $\begin{array}{c}0.006^{* * *} \\
(0.001)\end{array}$ \\
\hline \multicolumn{5}{|c|}{ Endogenous financial development variables } \\
\hline State-owned bank $i t$ & $\begin{array}{c}0.006^{* *} \\
(0.0014)\end{array}$ & $\begin{array}{c}-0.015 \\
(0.0298)\end{array}$ & $\begin{array}{l}0.007^{* * *} \\
(0.0021)\end{array}$ & $\begin{array}{c}-0.009 \\
(0.0304)\end{array}$ \\
\hline Domestic-private bank $_{i t}$ & $\begin{array}{l}0.028^{* * *} \\
(0.0031)\end{array}$ & $\begin{array}{c}0.033 \\
(0.0276)\end{array}$ & $\begin{array}{l}0.028^{* * *} \\
(0.0026)\end{array}$ & $\begin{array}{c}0.011 \\
(0.0164)\end{array}$ \\
\hline Foreign bank ${ }_{i t}$ & $\begin{array}{l}0.015^{* * *} \\
(0.0022)\end{array}$ & $\begin{array}{c}0.027 \\
(0.0199)\end{array}$ & $\begin{array}{l}0.014^{* * *} \\
(0.0021)\end{array}$ & $\begin{array}{c}0.019 \\
(0.0203)\end{array}$ \\
\hline Crisis $_{t} \times$ State-owned bank $_{i t}$ & $\begin{array}{l}0.018^{* * *} \\
(0.0021)\end{array}$ & $\begin{array}{c}0.023 \\
(0.0176)\end{array}$ & $\begin{array}{l}0.019^{* * *} \\
(0.0025)\end{array}$ & $\begin{array}{c}0.029 \\
(0.0197)\end{array}$ \\
\hline Crisis $_{t} \times{\text { Domestic-private } \text { bank }_{i t}}$ & $\begin{array}{c}-0.007^{* * *} \\
(0.0019)\end{array}$ & $\begin{array}{c}0.019 \\
(0.0179)\end{array}$ & $\begin{array}{c}-0.006^{* *} \\
(0.0023)\end{array}$ & $\begin{array}{c}0.024^{*} \\
(0.0121)\end{array}$ \\
\hline Crisis $_{t} \times$ Foreign bank $_{i t}$ & $\begin{array}{c}-0.006^{* * *} \\
(0.0019)\end{array}$ & $\begin{array}{l}-0.022^{*} \\
(0.0122)\end{array}$ & $\begin{array}{c}-0.005^{* * *} \\
(0.0019)\end{array}$ & $\begin{array}{l}-0.020^{*} \\
(0.0123)\end{array}$ \\
\hline \multicolumn{5}{|l|}{ Endogenous city-level characteristics } \\
\hline Gini index ${ }_{i t}$ & & & $\begin{array}{r}-0.192^{* * *} \\
(0.0442)\end{array}$ & $\begin{array}{r}-0.834^{* * *} \\
(0.2853)\end{array}$ \\
\hline HDI-Income $_{i t}$ & & & $\begin{array}{c}0.286^{* *} \\
(0.1138)\end{array}$ & $\begin{array}{l}3.474^{* * *} \\
(0.7341)\end{array}$ \\
\hline HDI-Education $_{i t}$ & & & $\begin{array}{l}0.339^{* * *} \\
(0.0614)\end{array}$ & $\begin{array}{c}0.097 \\
(0.3961)\end{array}$ \\
\hline HDI-Health $_{i t}$ & & & $\begin{array}{l}0.482^{* * *} \\
(0.1042)\end{array}$ & $\begin{array}{c}0.574 \\
(0.6720)\end{array}$ \\
\hline Number of observations & 55,070 & 55,070 & 55,070 & 55,070 \\
\hline Number of instruments & 52 & 52 & 52 & 52 \\
\hline AR-2 (p-value) & 0.142 & 0.237 & 0.183 & 0.237 \\
\hline Sargan (p-value) & 0.121 & 0.138 & 0.197 & 0.249 \\
\hline
\end{tabular}

Standard errors in parentheses

${ }^{*} p<0.10,{ }^{* *} p<0.05,{ }^{* * *} p<0.01$ 
Table 7: Regression results that test the role of bank type in economic growth. We run the dynamic panel-data specification: $Y_{i t}=\alpha+\rho Y_{i, t-1}+\beta$ Finance $_{i t}+\gamma$ Controls $_{i t}+\kappa$ Crisis $_{t}+\eta$ Crisis $_{t} \times$ Finance $_{i t}+\varepsilon_{i t} . Y_{i t}$ is the per capita GDP growth (Columns 1 and 3 ) and its volatility (Columns 2 and 4) for Brazilian municipalities. Finance $e_{i t}$ is our financial development variables: local credit growth rates granted by commercial, investment, development banks and credit unions in terms of local GDP. We interact them with Crisis ${ }_{t}$, a GFC dummy that starts in 2008. Controls $s_{i t}$ are city-level controls (Gini and HDI). We assume that financial development and city-level variables are endogenous and estimate the dynamic panel using Blundell and Bond (1998)'s System GMM. We report tests for second-order serial correlation (AR-2) and instrument validity (Sargan).

\begin{tabular}{|c|c|c|c|c|}
\hline & $\begin{array}{l}(1) \\
\text { Growth }\end{array}$ & $\begin{array}{c}(2) \\
\text { Volatility }\end{array}$ & $\begin{array}{l}(3) \\
\text { Growth }\end{array}$ & $\begin{array}{c}(4) \\
\text { Volatility }\end{array}$ \\
\hline $\begin{array}{l}\text { Autoregressive coefficient } \\
\text { Per capita growth } \\
i, t-1\end{array}$ & $\begin{array}{r}-0.030^{* * *} \\
(0.0093)\end{array}$ & $\begin{array}{c}0.007^{* * *} \\
(0.002)\end{array}$ & $\begin{array}{r}-0.032^{* * *} \\
(0.0096)\end{array}$ & $\begin{array}{c}0.008^{* * *} \\
(0.003)\end{array}$ \\
\hline $\begin{array}{l}\text { Endogenous financial developme } \\
\text { Commercial bank }_{i t}\end{array}$ & $\begin{array}{c}\text { t variables } \\
0.041^{* * *} \\
(0.0028)\end{array}$ & $\begin{array}{l}0.056^{* * *} \\
(0.0128)\end{array}$ & $\begin{array}{l}0.039^{* * *} \\
(0.0026)\end{array}$ & $\begin{array}{l}0.047^{* * *} \\
(0.0133)\end{array}$ \\
\hline Investment bank ${ }_{i t}$ & $\begin{array}{c}0.001 \\
(0.0007)\end{array}$ & $\begin{array}{c}-0.009^{*} \\
(0.0048)\end{array}$ & $\begin{array}{c}-0.002 \\
(0.0013)\end{array}$ & $\begin{array}{l}-0.011^{* *} \\
(0.0061)\end{array}$ \\
\hline Credit union $_{i t}$ & $\begin{array}{r}-0.012^{* * *} \\
(0.0011)\end{array}$ & $\begin{array}{c}-0.079^{* * *} \\
(0.0077)\end{array}$ & $\begin{array}{r}-0.007^{* * *} \\
(0.0019)\end{array}$ & $\begin{array}{r}-0.069^{* * *} \\
(0.0071)\end{array}$ \\
\hline Development bank $_{i t}$ & $\begin{array}{l}0.003^{* * *} \\
(0.0005)\end{array}$ & $\begin{array}{c}0.009 \\
(0.0057)\end{array}$ & $\begin{array}{l}0.003^{* * *} \\
(0.0005)\end{array}$ & $\begin{array}{c}0.006 \\
(0.0081)\end{array}$ \\
\hline Crisis $_{t} \times$ Commercial bank $_{i t}$ & $\begin{array}{c}-0.003 \\
(0.0067)\end{array}$ & $\begin{array}{c}-0.006 \\
(0.0094)\end{array}$ & $\begin{array}{c}0.009 \\
(0.0092)\end{array}$ & $\begin{array}{c}0.011 \\
(0.0109)\end{array}$ \\
\hline Crisis $_{t} \times$ Investment bank $_{i t}$ & $\begin{array}{c}-0.001 \\
(0.0006)\end{array}$ & $\begin{array}{c}0.002 \\
(0.0039)\end{array}$ & $\begin{array}{c}-0.001 \\
(0.0005)\end{array}$ & $\begin{array}{c}0.002 \\
(0.0032)\end{array}$ \\
\hline Crisis $_{t} \times$ Credit union $i t$ & $\begin{array}{l}0.002^{* * *} \\
(0.0005)\end{array}$ & $\begin{array}{l}0.026^{* * *} \\
(0.0035)\end{array}$ & $\begin{array}{c}0.001^{*} \\
(0.0005)\end{array}$ & $\begin{array}{l}0.023^{* * *} \\
(0.0035)\end{array}$ \\
\hline Crisis $_{t} \times$ Development bank $_{i t}$ & $\begin{array}{c}0.001 \\
(0.0009)\end{array}$ & $\begin{array}{c}-0.008^{* * *} \\
(0.0032)\end{array}$ & $\begin{array}{c}0.001 \\
(0.0007)\end{array}$ & $\begin{array}{l}-0.007^{* *} \\
(0.0030)\end{array}$ \\
\hline $\begin{array}{l}\text { Endogenous city-level character } \\
\text { Gini index }{ }_{i t}\end{array}$ & itics & & $\begin{array}{r}-0.224^{* * *} \\
(0.0277)\end{array}$ & $\begin{array}{r}-0.829^{* * *} \\
(0.1848)\end{array}$ \\
\hline HDI-Income $_{i t}$ & & & $\begin{array}{l}0.244^{* * *} \\
(0.0682)\end{array}$ & $\begin{array}{l}2.609^{* * *} \\
(0.5089)\end{array}$ \\
\hline HDI-Education $_{i t}$ & & & $\begin{array}{l}0.361^{* * *} \\
(0.0421)\end{array}$ & $\begin{array}{l}0.798^{* * *} \\
(0.2709)\end{array}$ \\
\hline HDI-Health $_{i t}$ & & & $\begin{array}{l}0.522^{* * *} \\
(0.0619)\end{array}$ & $\begin{array}{c}1.222^{* *} \\
(0.5314)\end{array}$ \\
\hline Number of observations & 55,070 & 55,070 & 55,070 & 55,070 \\
\hline Number of instruments & 52 & 52 & 52 & 52 \\
\hline AR-2 (p-value) & 0.166 & 0.168 & 0.173 & 0.177 \\
\hline Sargan (p-value) & 0.187 & 0.301 & 0.254 & 0.330 \\
\hline
\end{tabular}

Standard errors in parentheses

${ }^{*} p<0.10,{ }^{* *} p<0.05,{ }^{* * *} p<0.01$ 
After the GFC, only credit unions contributed to economic growth. The credit union sector has strengthened significantly since the 1990s, due in part to changes in regulation. By 2008, there were 1,451 credit unions in Brazil. The steady growth of cooperatives has also been accompanied by mergers and increased numbers of service points, both fruits of the search for economies of scale and rationalization measures that most sectors have implemented. Again, Gini Index affects negatively growth and volatility, while the HDI indexes for income, education and health, again, present a positive association.

\section{Robustness Tests}

In our baseline regressions, we tackled the potential endogeneity problem between financial development variables and economic growth using internal instruments in a dynamic panel-data model. In this section, we report robustness tests in which we use external instruments for financial development variables, namely (i) the number of complaints that are filed against banks within a city and (ii) credit accessibility inside the city.

\subsection{Credit growth instrumented by the number of complaints}

We instrument credit / GDP growth using the number of complaints that banks within a city receive over the year. Every citizen in Brazil can file a complain against a bank using the $R D R$ Reclamações, which is maintained by the $\mathrm{BCB} .97 \mathrm{We}$ instrument credit (over GDP) demand inside a city by counting the number of complaints that are filed by residents that live inside the city against banks that also operate in the same municipality over each year. Due to data limitation, our sample goes from 2007 to 2014. Therefore, this empirical exercise will not be able to capture potential changes that happened in view of the GFC onset.

Figure 5 portrays the distribution of the number of complaints filed against each bank by local residents in Brazil from 2007 to 2014. The Southeast region detains the largest number of complaints largely because it holds the largest quantity of bank branches, has the largest outstanding bank credit in Brazil, and also has the largest financially active population. The North region also has a significant number of complaints even though the banking system is one of the least representatives in the country.

We use the following econometric specification:

$$
Y_{i t}=\alpha_{i}+\alpha_{t}+\beta \text { Finance }_{i t}+\gamma \text { Controls }_{i, t-1}+\varepsilon_{i t},
$$

in which $\alpha_{i}$ and $\alpha_{t}$ are city and time fixed effects that capture time-invariant city-specific and homogeneous time-varying characteristics, respectively. We estimate the specification using a two-stage

\footnotetext{
${ }^{9} \mathrm{RDR}$ is one of the instruments that the BCB uses in its regulation and monitoring process of the financial system.
} 


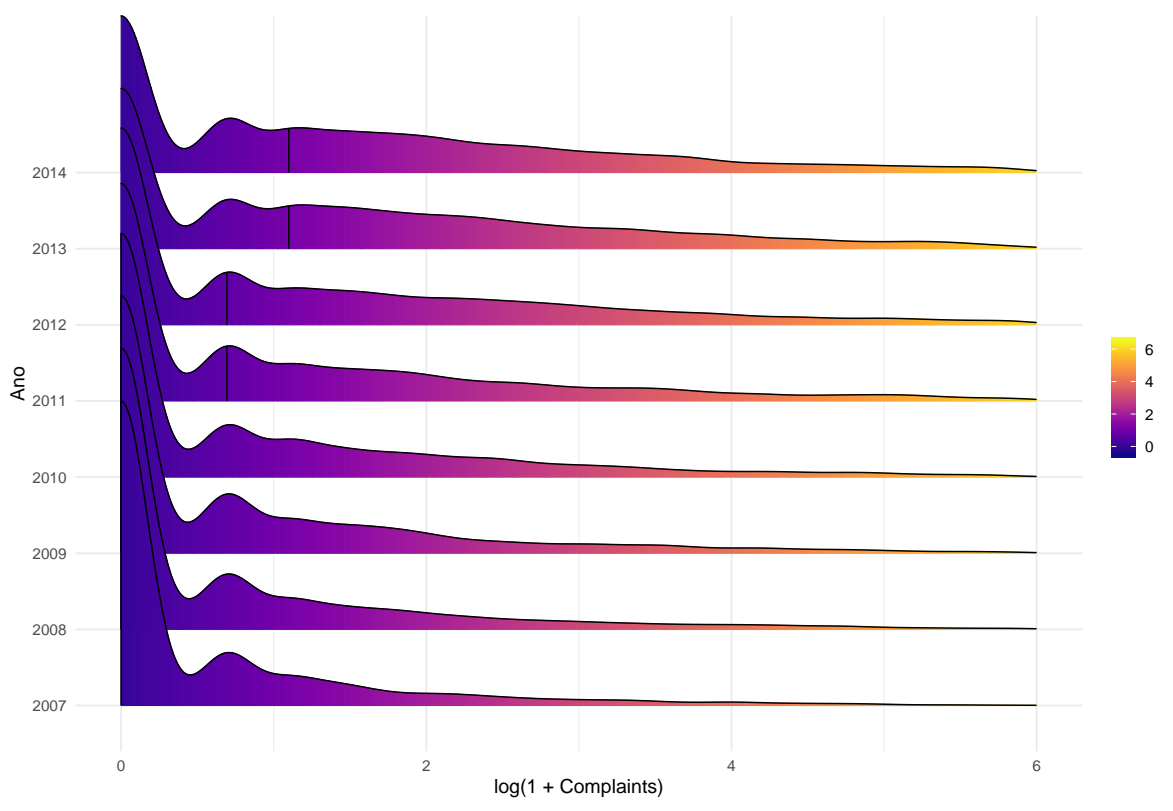

Figure 5: Distribution of the number of complaints filed against each bank in Brazil from 2007 to 2014. The vertical line at each distribution denotes the median value.

instrumental regression, in which we instrument Finance $_{i t}$, the financial development variables, with the lagged number of complaints. We use the same municipality-level controls, Gini and HDI (Income, Education, Health), but with lagged values to prevent biasing our estimates. We use two-way clustering on city and time for robust standard errors.

We believe our instrument is relevant for the following reason. We expect that an increase in the previous year's number of complaints will generate a contraction in the outstanding credit / GDP of the bank in the city, which is consistent with the fact that citizens search for bank services with quality. If bank services have low quality, then borrowers file a formal complaint against that bank and new borrowers will internalize that bad information about the bank in the subsequent periods. In this case, we expect that the share of credit over GDP inside the city will decrease, as new borrowers will replace troublesome banks by banks with higher standards. For the exclusion restriction, we argue that increases in the number of complaints have little to do with the municipal economic growth, as they are only related to the internal services that banks grant to customers after credit is already issued.

We instrument only the following financial development variables: (i) the total outstanding credit / GDP growth and (ii) credit / GDP growth that is granted by state-owned, domestic private, and foreign banks. 10 Figure 6 shows a scatter plot of the total outstanding credit / GDP against the lagged value of the number of complaints filed against banks operating in each Brazilian city, which suggests a negative statistical relationship between both variables.

Table 8 reports the results for the first stage of the instrumental regression, which tests the

\footnotetext{
${ }^{10}$ We do not run regressions using credit modality because we cannot identify which credit modality the citizen that is filing a complain has taken with the bank. In addition, we do not run regressions using financial development broke down by bank type because of lack of data on credit unions and development banks.
} 


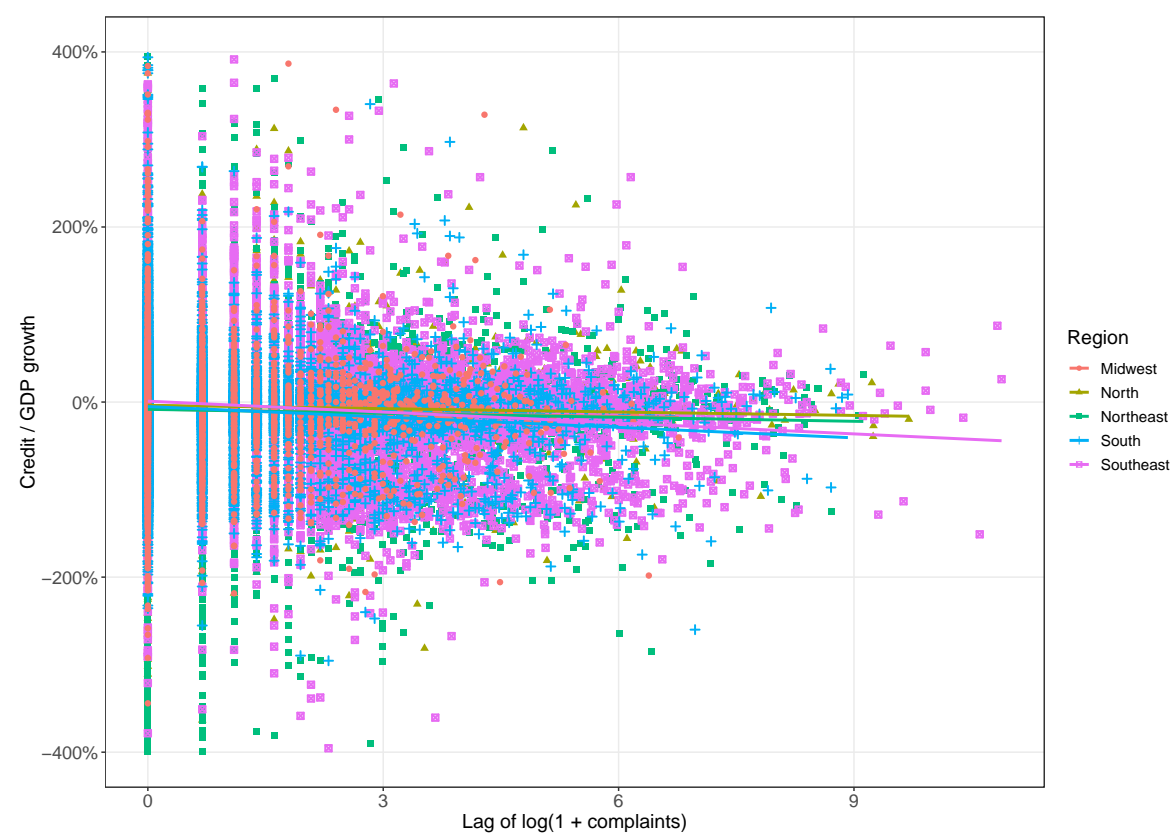

Figure 6: Scatter plot of the total outstanding credit / GDP against the lagged value of the number of complaints filed versus banks operating in each Brazilian city. We aggregate the number of complaints of all banks within the city. We stack values in the same plot from years 2008 to 2014. Colors portray the region at where the city is.

instrument relevance. Following the rule of thumb in the econometric literature, we can see that the t-statistics remain above 3 and that the F-statistic is above 10 in every specification, which confirms the relevance of our instrument. In addition, we see a negative statistical sign for the relationship between financial development and number of complaints, which corroborates the scatter plot in Fig. 6.

Table 8: First stage results of our instrumental regression. We test the instrument relevance (lagged number of complaints) for the instrumented variable (credit / GDP growth).

\begin{tabular}{|c|c|c|c|c|}
\hline \multirow[t]{5}{*}{ Sample Period: $2008-2014$} & \multicolumn{4}{|c|}{ First stage } \\
\hline & \multicolumn{4}{|c|}{ Credit / GDP Growth it } \\
\hline & (1) & (2) & (3) & (4) \\
\hline & All & State-owned & Domestic Private & Foreign \\
\hline & Complaints & Complaints & Complaints & Complaints \\
\hline Complaints $_{i, t-1}$ & $\begin{array}{c}-0.024^{* * *} \\
(0.009)\end{array}$ & $\begin{array}{c}-0.012^{* * *} \\
(0.003)\end{array}$ & $\begin{array}{c}-0.042^{* * *} \\
(0.013)\end{array}$ & $\begin{array}{c}-0.085^{* * *} \\
(0.021)\end{array}$ \\
\hline F Statistic & 18.29 & 13.29 & 19.22 & 17.09 \\
\hline
\end{tabular}

Table 9 shows results for the second stage of the instrumental regression that run from 2008 to 2014 (after the GFC). In Column (1), we regress economic growth on total outstanding credit, which is instrumented by the total number of complaints of residents inside the city. We get an elasticity of $2.1 \%$ for an increase in the total outstanding credit / GDP growth. In Column (2), we break down credit in terms of bank control: state-owned, domestic private, and foreign banks. We find that stateowned and domestic private banks have elasticities of $2.9 \%$ and $2.3 \%$. All estimates are near the net 
elasticities found in our baseline regressions using the GMM with internal instruments. Contrary to our baseline regressions, we do not find empirical evidence of foreign banks in fostering economic growth after the GFC.

Table 9: Second stage results for our instrumental regression. We test whether financial development matters for economic growth. We instrument the endogeneous financial development variables with lagged values of the number of complaints. We run the following static panel $Y_{i t}=\alpha_{i}+\alpha_{t}+\beta$ Finance $_{i t}+\gamma$ Controls $_{i, t-1}+\varepsilon_{i t}$, in which $Y_{i t}$ is per capita GDP growth of city $i$ at time $t, \alpha_{i}, \alpha_{t}$ are city and time fixed effects, Finance ${ }_{i t}$ are the instrumented financial development variables (Column (1): total oustanding credit / GDP growth and Column (2): credit / GDP growth by bank control), Controls $i_{i, t-1}$ are lagged controls. We use lagged controls to prevent biasing our estimates, and $\varepsilon_{i t}$ is the error term. We use two-way error clustering on city and time to get robust standard errors.

\begin{tabular}{|c|c|c|}
\hline \multirow[t]{3}{*}{ Sample Period: 2008-2014 } & \multicolumn{2}{|c|}{ Second Stage } \\
\hline & \multicolumn{2}{|c|}{ Per Capita municipality-level Growth } \\
\hline & $(1)$ & $(2)$ \\
\hline Instrumented Total Credit ${ }_{i t}$ & $\begin{array}{l}0.021^{* * *} \\
(0.0067)\end{array}$ & \\
\hline Instrumented State-Owned Credit ${ }_{i t}$ & & $\begin{array}{l}0.029^{* * *} \\
(0.0010)\end{array}$ \\
\hline Instrumented Domestic Private Credit ${ }_{i t}$ & & $\begin{array}{l}0.023^{* * *} \\
(0.0069)\end{array}$ \\
\hline Instrumented Foreign Credit ${ }_{i t}$ & & $\begin{array}{c}0.003 \\
(0.0027)\end{array}$ \\
\hline City Fixed effects? & Yes & Yes \\
\hline Time Fixed effects? & Yes & Yes \\
\hline municipality-level controls? & Yes & Yes \\
\hline Error clustering & City + Year & City + Year \\
\hline Number of Observations & 38,869 & 38,869 \\
\hline $\mathrm{R}^{2}$ & 0.362 & 0.427 \\
\hline
\end{tabular}

\subsection{Credit growth instrumented by local credit accessibility}

In this section, we provide additional robustness tests for our claims using another external instrument for credit / GDP growth: the local credit accessibility. We construct the credit accessibility variable by counting the number of bank branches that exist in the microregion ${ }^{11}$ using data from ESTBAN, which is a public bank branch-city-time panel data maintained by the BCB. We use data from 2004 to 2014, which enables us to investigate potential changes in the bank influence on economic growth after the GFC.

We compute the local credit accessibility of a specific city $i$ at time $t$ using the expression:

\footnotetext{
${ }^{11} \mathrm{~A}$ microregion is a set of contiguous cities that share similar social and economic characteristics.
} 


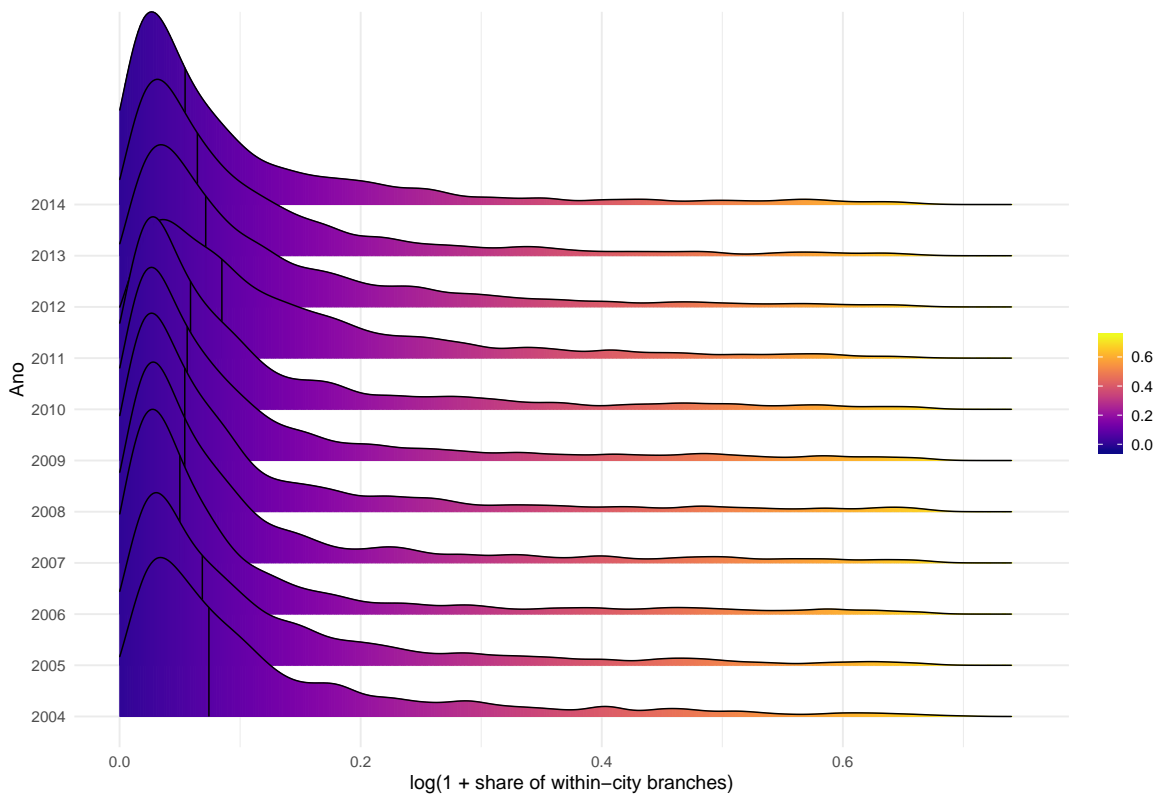

Figure 7: Distribution of the share of within-city branches to the total number of branches in the city's microregion. Each point represents data for a Brazilian city from 2004 to 2014. The vertical line at each distribution denotes the median value.

$$
\text { Credit Accessibility }_{i t}=\frac{\text { Number of branches in city } i \text { at time } t}{\text { Number of branches in microregion of } i \text { at time } t} .
$$

We also instrument credit / GDP growth broken down by bank control (state-owned, domestic private, or foreign) by simply counting the number of branches conditioned on the bank control in the numerator while letting the denominator unchanged in (3).

In relation to the instrument relevance, we expect that increases in credit accessibility will lead to higher credit shares in the local market. One underlying hypothesis is that citizens, in general, conveniently choose nearby banks to perform their financial transactions. In what concerns the exclusion restriction, while there may be correlation between the number of bank branches and economic growth through the error term, we believe that such effect is less pronounced than using the financial development variable per se in the regression. In this way, we alleviate the endogeneity but do not prevent it. For instance, banks can open new branches in prosperous municipalities with high economic growth as credit demand will likely increase.

Figure 7 shows the distribution of local credit accessibility in cities from 2007 to 2014 . We observe a decrease in credit accessibility after 2011 in Brazil. Figure 8 shows a scatter plot of the credit / GDP growth against the lagged credit accessibility variable, which suggests a positive relationship between both variables in all Brazilian states.

In Table 10, we present results for the first stage of the instrumental regression, which allows us to test the instrument relevance. Our t-statistics are all above 3 and the F-statistic is above 10, confirming our choice of the instrument. We also can see a positive statistical sign for the relation- 


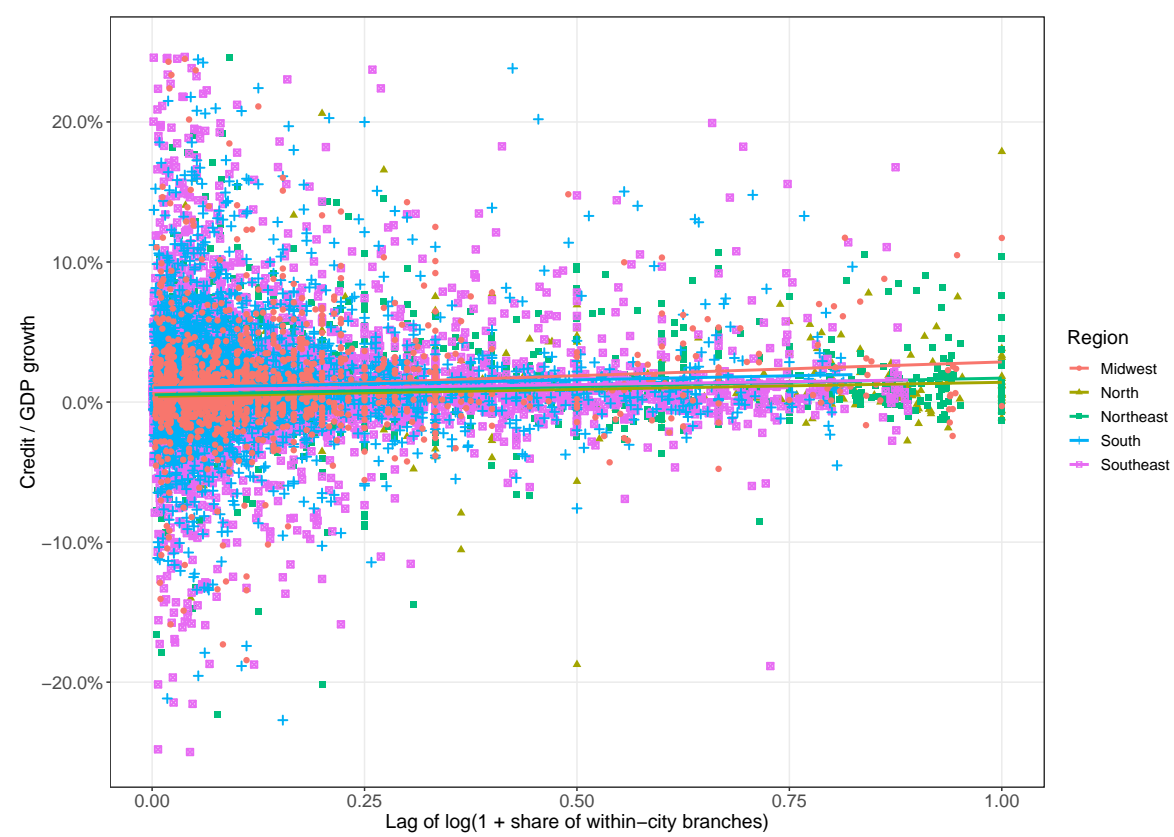

Figure 8: Scatter plot of the total outstanding credit / GDP against the lagged value of the share of the number of withincity branches to the total number of branches in the city's microregion. We stack values in the same plot from years 2004 to 2014. Colors portray the region at where the city is.

ship between financial development and the share of branches (total and split by bank type), which corroborates the scatter plot in Fig. 8 .

In Table 11, we present results for the second stage of the instrumental regression. Since we have pre- and post-crisis data, we use a crisis dummy to test for potential differences in the bank credit role in fostering economic growth. In Column (1), we regress economic growth on total outstanding credit, and use as instrument the share of branches in each municipality. We get an elasticity of $1.9 \%$ for an increase in the total outstanding credit / GDP growth. After the GFC, the importance of credit increases even further (by 0.6\%). In Column (2), we break down credit / GDP growth in terms of bank control: state-owned, domestic private, and foreign banks. We find that state-owned, domestic private and foreign banks have elasticities of $0.8 \%, 3.4 \%$ and $1.1 \%$, respectively, all of which statistically significant. After the GFC, the role of state-owned banks increases while that of domestic private banks decreases. The importance of foreign banks after the GFC becomes economically irrelevant.

Our results suggest that even after employing external instruments for financial development, we find qualitatively similar results, suggesting robustness in our results.

\section{Conclusion}

In this paper, we bring new evidence to the debate of the nexus between financial development and city growth. The role of banks and their specific characteristics are taken into account. We analyze the growth of 5,555 Brazilian municipalities by employing a detailed dataset of 66,271 observations. Our motivation is the lack of a precisely conclusion in what concerns the finance-growth nexus. 
Table 10: First stage results of our instrumental regression. We test the instrument relevance (lagged credit accessibility) for the instrumented variable (credit / GDP growth).

\begin{tabular}{|c|c|c|c|c|}
\hline \multirow[t]{6}{*}{ Sample Period: 2004-2014 } & \multicolumn{4}{|c|}{ First stage } \\
\hline & \multicolumn{4}{|c|}{ Credit / GDP Growth } \\
\hline & (1) & (2) & (3) & (4) \\
\hline & Share of & Share of & Share of & Share of \\
\hline & Branches & State-owned & Domestic Private & Foreign \\
\hline & & Branches & Branches & Branches \\
\hline Credit accessibility $_{i, t-1}$ & $\begin{array}{c}0.033^{* * *} \\
(0.006)\end{array}$ & $\begin{array}{c}0.037^{* * *} \\
(0.004)\end{array}$ & $\begin{array}{c}0.029^{* * *} \\
(0.001)\end{array}$ & $\begin{array}{c}0.021^{* * *} \\
(0.005)\end{array}$ \\
\hline F Statistic & 14.18 & 21.14 & 28.97 & 11.83 \\
\hline
\end{tabular}

We find that cities with more shares of non-earmarked credit associate stronger with higher economic growth rates than those with more shares of non-earmarked credit. However, after the GFC, earmarked credit gained more relevance. In terms of credit modality, we verify that purposespecific credit is the modality that correlates more with positive economic growth rates relative to general loans and other types of credit. However, after the GFC, general purpose loans take a stronger role in the economic growth of municipalities.

Credit from domestic private banks also has a stronger association with economic growth relative to credit from state-owned and international banks. However, after the crisis, the relative importance of state-owned banks increased while that of domestic private and foreign decreased. In what concerns bank type, commercial banks have the highest positive association with growth and its volatility across Brazilian cities. After the GFC, only credit unions had statistically significant partial correlation with economic growth.

We also find that other indicators, not only financial development, correlate with economic growth, such as income distribution and the economic development of Brazil. Lastly, the GFC had a significant impact over Brazilian credit and external accounts. Therefore, our paper provides empirical evidence that financial development has a strong connection with economic growth and that such link depends on credit- and bank-specific characteristics, such as their ownership and type.

As robustness, we also run regressions in which we design external instruments for financial development variables. We instrument credit growth in a specific city with the number of complaints that residents in that city filed against each bank in the previous year. The intuition is that, the more complaints a bank has, the less is its credit growth. We also instrument credit growth with a proxy for credit accessibility within the city: the larger the number of branches a bank has within the city, the easier (more convenient) it is to take credit. Our results with external instruments indicate the same findings with respect to the use of traditional internal instruments in GMM estimations. 
Table 11: Second stage results for our instrumental regression. We test whether financial development matters for economic growth. We instrument the endogeneous financial development variables with lagged values of the share of bank branches at each municipality. We run the following static panel $Y_{i t}=\alpha_{i}+\alpha_{t}+\beta$ Finance $_{i t}+\gamma$ Controls $_{i, t-1}+\varepsilon_{i t}$, in which $Y_{i t}$ is per capita GDP growth of city $i$ at time $t, \alpha_{i}, \alpha_{t}$ are city and time fixed effects, Finance $e_{i t}$ are the instrumented financial development variables (Column (1): total oustanding credit / GDP growth and Column (2): credit / GDP growth by bank control), Controls $s_{i, t-1}$ are lagged controls. We use lagged controls to prevent biasing our estimates, and $\varepsilon_{i t}$ is the error term. We use two-way error clustering on city and time to get robust standard errors.

Sample Period: 2004-2014 Second Stage

Per Capita municipality-level Growth

(1) (2)

\begin{tabular}{lc}
\hline Instrumented Total Credit $_{i t}$ & $\begin{array}{l}0.019^{* * *} \\
(0.0059)\end{array}$ \\
Crisis $_{t} \times$ Instrumented Total Credit $_{i t}$ & $0.006^{* * *}$ \\
& $(0.0021)$
\end{tabular}

Instrumented State-Owned Credit ${ }_{i t}$ $0.008^{*}$

Instrumented Domestic Private Credit ${ }_{i t}$ $0.034^{* * *}$

(0.0094)

Instrumented Foreign Credit ${ }_{i t}$ $0.011^{\text {** }}$

Crisis $_{t} \times$ Instrumented State-Owned Credit $_{i t}$ $0.023^{* * *}$

Crisis $_{t} \times$ Instrumented Domestic Private Credit $_{i t}$

Crisis $_{t} \times$ Instrumented Foreign Credit $_{i t}$

\begin{tabular}{lcc}
\hline City Fixed effects? & Yes & Yes \\
Time Fixed effects? & Yes & Yes \\
municipality-level controls? & Yes & Yes \\
Error clustering & City + Year & City + Year \\
Number of Observations & 55,070 & 55,070 \\
$\mathrm{R}^{2}$ & 0.362 & 0.427 \\
\hline \hline Note: & ${ }^{*} \mathrm{p}<0.1 ;{ }^{* *} \mathrm{p}<0.05 ;{ }^{* * *} \mathrm{p}<0.01$
\end{tabular}




\section{References}

Abedifar, P., Hasan, I., and Tarazi, A. (2016). Finance-growth nexus and dual-banking systems: Relative importance of islamic banks. Journal of Economic Behavior and Organization, 132:198215.

Aghion, B. A. (1999). Development banking. Journal of Development Economics, 58(1):83-100.

Aghion, P., Caroli, E., and Garcia-Penalosa, C. (1999). Inequality and economic growth: the perspective of the new growth theories. CEPREMAP Working Papers (Couverture Orange) 9908, CEPREMAP.

Barajas, A., Chami, R., and Yousefi, R. (2013). The Finance and Growth Nexus Re-Examined; Do All Countries Benefit Equally? IMF Working Papers 13/130, International Monetary Fund.

Beck, R., Georgiadis, G., and Straub, R. (2014a). The finance and growth nexus revisited. Economics Letters.

Beck, T., Degryse, H., and Kneer, C. (2014b). Is more finance better? disentangling intermediation and size effects of financial systems. Journal of Financial Stability, 10:50-64.

Beck, T., Demirgüç-Kunt, A., and Levine, R. (2007). Finance, inequality and the poor. Journal of Economic Growth, 12(1):27-49.

Beck, T. and Levine, R. (2004). Stock markets, banks, and growth: Panel evidence. Journal of Banking and Finance, 28(3):423-442.

Beck, T., Levine, R., and Loayza, N. (2000). Finance and the sources of growth. Journal of Financial Economics, 58(1-2):261-300.

Beck, T., Lu, L., and Yang, R. (2015). Finance and growth for microenterprises: Evidence from rural china. World Development, 67:38-56.

Beck, T., Lundberg, M., and Majnoni, G. (2006). Financial intermediary development and growth volatility: Do intermediaries dampen or magnify shocks? Journal of International Money and Finance, 25(7):1146-1167.

Blundell, R. and Bond, S. (1998). Initial conditions and moment restrictions in dynamic panel data models. Journal of Econometrics, 87(1):115-143.

Bonomo, M., Brito, R. D., and Martins, B. (2015). The after crisis government-driven credit expansion in Brazil: A firm level analysis. Journal of International Money and Finance, 55(C):111-134.

Bos, J. W. B., Economidou, C., Koetter, M., and Kolari, J. W. (2010). Do all countries grow alike? Journal of Development Economics, 91(1):113-127.

Breitenlechner, M., Gächter, M., and Sindermann, F. (2015). The finance-growth nexus in crisis. Economics Letters, 132:31-33. 
Clarke, G. R. G. (1995). More evidence on income distribution and growth. Journal of Development Economics, 47(2):403-427.

Costa, A. C. A. and Mello, J. M. P. D. (2008). Judicial Risk and Credit Market Performance: Micro Evidence from Brazilian Payroll Loans. In Financial Markets Volatility and Performance in Emerging Markets, NBER Chapters, pages 155-184. National Bureau of Economic Research, Inc.

De Mello, J. M. P. and Garcia, M. G. (2012). Bye, bye financial repression, hello financial deepening: The anatomy of a financial boom. The Quarterly Review of Economics and Finance, 52(2):135153.

Demetriades, P. O. and Hussein, K. A. (1996). Does financial development cause economic growth? Time-series evidence from 16 countries. Journal of Development Economics, 51(2):387-411.

Demirguc-Kunt, A. and Levine, R. (2008). Finance and economic opportunity. Policy Research Working Paper Series 4468, The World Bank.

Doumpos, M., Hasan, I., and Pasiouras, F. (2017). Bank overall financial strength: Islamic versus conventional banks. Economic Modelling, 64(C):513-523.

Easterly, W., Islam, R., and Stiglitz, J. (2001). chapter shaken and stirred: Explaining growth volatility. Annual World Bank Conference on Development Economics 2000, The World Bank, pages 191-211.

Easterly, W. and Levine, R. (2003). Tropics, germs, and crops: how endowments influence economic development. Journal of Monetary Economics, 50(1):3-39.

Haber, S. (2008). African Finance for the 21 st Century High-Level Seminar organized by the IMF Institute in collaboration with the Joint Africa Institute The Finance-Growth Nexus: Theory, Evidence, and Implications for Africa. Technical report.

Hasan, I., Koetter, M., and Wedow, M. (2009). Regional growth and finance in Europe: Is there a quality effect of bank efficiency? Journal of Banking \& Finance, 33(8):1446-1453.

Hasan, M. and Dridi, J. (2011). The Effects Of The Global Crisis On Islamic And Conventional Banks: A Comparative Study. Journal of International Commerce, Economics and Policy, 2(02):163-200.

Herwartz, H. and Walle, Y. M. (2014). Openness and the finance-growth nexus. Journal of Banking and Finance, 48:235-247.

Jayaratne, J. and Strahan, P. E. (1996). The finance-growth nexus: Evidence from bank branch deregulation. The Quarterly Journal of Economics, 111(3):639-670.

King, R. G. and Levine, R. (1993). Finance and Growth: Schumpeter Might be Right. The Quarterly Journal of Economics, 108:717-738. 
Koop, G., Osiewalski, J., and Steel, M. F. J. (2000). Modeling the sources of output growth in a panel of countries. Journal of Business \& Economic Statistics, 18(3):284-299.

Law, S. H., Azman-Saini, W., and Ibrahim, M. H. (2013). Institutional quality thresholds and the finance - growth nexus. Journal of Banking and Finance, 37(12):5373-5381.

Law, S. H. and Singh, N. (2014). Does too much finance harm economic growth? Journal of Banking and Finance, 41:36-44.

Levine, R. (1999). Law, Finance, and Economic Growth. Journal of Financial Intermediation, 8:835.

Levine, R. (2005). Chapter 12 Finance and Growth: Theory and Evidence. Handbook of Economic Growth, 1(SUPPL. PART A):865-934.

Loayza, N. V. and Ranciere, R. (2006). Financial Development, Financial Fragility, and Growth. Journal of Money, Credit and Banking, 38(4):1051-1076.

Mallick, D. (2009). Financial Development, Shocks, and Growth Volatility. MPRA Paper 17799, University Library of Munich, Germany.

Masih, R. and Peters, S. (2010). A revisitation of the savings-growth nexus in mexico. Economics Letters, 107(3):318-320.

Nyankomo, M. and Stephen, Z. (2015). A review of finance-growth nexus theories: How does development finance fits in? Studies in Business and Economics, 10(1):83-91.

Persson, T. and Tabellini, G. (1994). Is Inequality Harmful for Growth? American Economic Review, 84(3):600-621.

Schiavo, S. and Vaona, A. (2008). Poolability and the finance-growth nexus: A cautionary note. Economics Letters, 98(2):144-147.

Silva, S. H. d., Tabak, B. M., Cajueiro, D. O., and Fazio, D. M. (2017). Economic growth, volatility and their interaction: What's the role of finance? Economic Systems, 41(3):433-444.

Soedarmono, W., Hasan, I., and Arsyad, N. (2017). Non-linearity in the finance-growth nexus: Evidence from indonesia. International Economics, 150:19-35.

Staub, R. B., da Silva e Souza, G., and Tabak, B. M. (2010). Evolution of bank efficiency in Brazil: A DEA approach. European Journal of Operational Research, 202(1):204-213.

Tabak, B. M., Fazio, D. M., and Cajueiro, D. O. (2011). The effects of loan portfolio concentration on Brazilian banks' return and risk. Journal of Banking \& Finance, 35(11):3065-3076.

Torres, E. and Zeidan, R. (2016). The life-cycle of national development banks: The experience of Brazil's BNDES. The Quarterly Review of Economics and Finance, 62(C):97-104. 